\title{
A Eclesiologia de Comunhão de Yves Congar e sua Relevância para a Igreja de Hoje
}

\author{
Eva Aparecida Rezende de Moraes
}

\section{Introdução}

Este artigo busca apresentar alguns elementos do pensamento de Yves Marie-Joseph Congar acerca da Igreja-Comunhão e, a partir dos mesmos, as conseqüências teológico-pastorais para a renovação da teologia e das estruturas da Igreja. Esta gama temática possui sua pertinência e pontualidade para a Igreja de hoje e de sempre - de hoje principalmente, devido à série de releituras e reflexões feitas ao Concílio Ecumênico do Vaticano II (Vat II) e à proximidade da realização da $\mathrm{V}$ Conferência da Igreja latino-americana, aqui, no Brasil.

Após um Concílio como foi o Vat II, em toda sua profundidade dogmática e essência de relacionalidade, e frente ao mundo atual, necessitamos resgatar, com urgência, o tema da comunhão. Atualmente, muito se tem escrito a esse respeito, mas nem sempre percebemos a preocupação de estabelecer delimitações teológicas necessárias a esse conceito, e de viver concretamente essa essência da Igreja. $\mathrm{O}$ tema da comunhão como realidade essencial da Igreja é, a nosso ver, de grande pertinência a qualquer época da Igreja, mas, principalmente a atual, e identificamos Yves Congar como o teólogo que melhor apresenta tal reflexão, com coragem, competência e pertinácia.

Estudar a eclesiologia de comunhão de Congar nos leva a encontrar aquela do Vat II. Elas não são idênticas, sendo, porém, inseparáveis. Vez ou 
outra, estaremos nos referindo a esse Concílio, rastreando o pensamento de Congar nas linhas de suas obras: Congar está impregnado dele, imbuído, e vice-versa. Ambos são profundamente implicados. Destaque especial dessa implicação é dado à Constituição Dogmática Lumen gentium (LG), a carta magna do Concílio, citada por Congar freqüentemente em suas obras posteriores. Ele empenhou-se neste Concílio, tanto preparando-o, influenciando-o, com suas pesquisas e trabalhos anteriores, e vivenciando-o; refere-se ao mesmo com sentimento: o concílio do aggiornamento ${ }^{1}$.

Neste artigo, ousamos estabelecer o status quaestionis da eclesiologia da comunhão. Sob nossa ótica, entendemos que, tanto a reflexão de Congar quanto a do Vat II, são um ponto de partida e, não, de chegada. Nem tanto devido aos anos que nos separam - cronologicamente, não são tantos assim , mas no tocante à intensa mudança cultural (tida por muitos como paradigmática) dos últimos tempos. Frente a este mundo a ser sempre e melhor evangelizado, a chave de articulação é uma autêntica reflexão trinitária, que parta, metodologicamente, das relações pericoréticas como inspiração e base de discernimento e reflexão para alguns dos principais elementos constitutivos da eclesiologia da comunhão. Congar reconhece que muitos fiéis e até teólogos se interessam por outros problemas, que não os das estruturas e dos ministérios eclesiásticos e eclesiais; para ele, porém, estes temas possuem uma importância decisiva ${ }^{2}$.

Congar, em suas obras, apresenta uma verdadeira gama de elementos constitutivos da eclesiologia de comunhão. Buscamos, aqui, selecionar alguns, usando nossos próprios critérios, como, por exemplo, o nível de importância e profundidade de fundamentação para tal eclesiologia e a constância com que emergem das obras do autor. Apesar de sentirmos como um prejuízo, não nos deteremos sobre aspectos da eclesiologia de comunhão na experiência das Igrejas Protestante e Ortodoxa, delimitando-nos ao campo de eclesiologia católica.

\section{O teólogo e eclesiólogo Yves Congar}

Yves Marie-Joseph Congar é conhecido em nosso meio teológicopastoral como o eclesiólogo dos leigos ${ }^{3}$. Ele seguiu, na matéria do laicato, uma linha muito coerente e contínua. Para ele, dois grandes dados marcaram

\footnotetext{
${ }^{1}$ Cf. CONGAR, Yves. El Espiritu Santo. Sección de Teología y Filosofia. Barcelona. Editorial Herder. 1991 ${ }^{2}$. P. 199.

${ }^{2}$ Cf. idem. Ministères et Communion Ecclésiale. Les Éditions du Cerf. Paris. 1971. P. 8.

${ }^{3}$ Cf. BRITO, Enio. O leigo cristão no mundo e na Igreja. Coleção Fé e Realidade, VII. São Paulo. Edições Loyola. 1980.
} 
o ponto de partida de sua reflexão mais formal: seu desejo de trabalhar na renovação da eclesiologia, e seu contato com um laicato chamado a abrir a Igreja - sobretudo, em sua época, sob a forma da Ação Católica.

Segundo ainda nosso autor, um bom número dos seus escritos emana da experiência e da realidade dos leigos, o que, para ele, manifesta uma nova tomada de consciência da parte dos mesmos: eles se sentem Igreja e têm, de certa forma, que construí-la, tornam-se responsáveis por ela ${ }^{4}$. Congar levou a sério seu trabalho de construção de uma teologia do laicato; releu, principalmente nos últimos anos de vida, algumas de suas obras (como Jalons pour une théologie du lä̈cat), fazendo, ele mesmo, suas próprias correções e ponderações ${ }^{5}$.

Congar relata que, nos anos de 1950-1952 - contexto do pré-Vat II ao preparar seu livro sobre o laicato (Jalons pour une théologie du laïcat), investigou não somente nos textos como também nos fatos da história antiga da Igreja, e descobriu, em toda parte, através das gerações e nos quadros da fé, do culto, do apostolado e da vida social da Igreja, a união entre a estrutura hierárquica e o exercício comunitário de todas as atividades eclesiais - ou seja: os leigos tinham uma parte ativa em toda a vida da Igreja. Congar também é conhecido como o teólogo do modelo eclesiológico Povo de Deus assumido, também, como fundamental, pelo Vat II. Este modelo é importante: parte da experiência fundamental cristã, assumindo a Igreja como povo de Deus, nascido da e chamado à comunhão pericorética intratrinitária. É sobre este tópico que nos demoraremos mais neste artigo.

A reflexão teológica de Congar é alimentada por uma profunda espiritualidade; e ele partilha sua experiência de Deus de forma despojada e corajosa. A comunhão refletida e vivida por Congar torna-se, para ele, como que o estatuto epistemológico para a vivência do ser Igreja. Sua vivência da comunhão se retrata nas linhas e entrelinhas de suas obras, quando, inclusive, vez ou outra, intuímos momentos de dor ao escrever algumas passagens principalmente nas páginas eclesiológicas, quando trata, por exemplo, do silêncio que lhe foi imposto pela Igreja ${ }^{6}$. Nosso autor relata o preço dessa atitude: marginalização, silêncio, inação... Afirma que não se assegura a unidade na Igreja mediante pressão ou redução a uma cópia conforme, mas, pela via delicada da comunhão!

Congar acredita possuir um pensamento solidamente fundado, mas alerta-nos que é o pensamento de um homem em busca, mais que a doutrina

\footnotetext{
${ }^{4} \mathrm{Cf}$. CONGAR, Yves. Vraie et fausse reforme dans l'Église. Les Éditions du Cerf. Paris. 1968. P. 18.

${ }^{5}$ Cf. idem. Ministères et Communion Ecclésiale. Ob. cit. P. $15 \mathrm{~s}$.

${ }^{6}$ Cf. idem. El Espíritu Santo. Ob. cit. P. 220-221.
} 
de uma Igreja ou de uma Escola ${ }^{7}$. Congar possui uma linguagem simples e acessível, retornando a expressões mais compreensíveis e sensíveis da fé, o que entendemos como relevante e pertinente para um mundo hoje, tão defensor do acessível e imediato. Por outro lado, isto não impede que ele use de ousadia e criatividade quando, com cuidado de fundamentação mas sem receio, questiona alguns termos eclesiológicos já consagrados até sua época ${ }^{8}$.

Uma das recentes descobertas acerca de seu pensamento refere-se à sua sistematização pneumatológica, que se revelou profundamente trinitária, relacional, integradora das relações divinas, humanas e eclesiais ${ }^{9}$. Congar apresentará a pneumatologia como uma teologia e uma dimensão profundamente importante para a eclesiologia; mas, adverte-nos de que a mesma somente encontrará seu pleno desenvolvimento naquilo que se realize e viva na Igreja - para ele, nesta área, a teoria depende amplamente da praxis ${ }^{10}$.

Ele nos diz que suas obras são ofertadas à apreciação de todos os seus leitores, mas, sobretudo, ao julgamento da Igreja. Nos esclarece que as suas críticas à Igreja não são negativas, mas fruto de amor total a ela e de confiança absoluta na Verdade. Congar acreditava somente poder servir à Verdade, através de uma sinceridade absoluta e total - ou seja, honrar a verdade em toda sua dimensão, segundo todos os seus aspectos, e no respeito de tudo o que deve ser respeitado. Outro alimento da sua vida são as Escrituras Sagradas; aliás, torna-se um homem profundamente decepcionado, quando encontra pela frente uma teologia analítica, em detrimento de uma que parta das Escrituras ${ }^{11}$.

Enfim, encerrando essa breve apresentação de Congar, queremos reafirmar ser ele um homem dotado de um profundo amor pela Igreja, que não deixa, entretanto, que tal profundidade de sentimento obscureça um olhar mais apurado e crítico sobre a realidade eclesial. Congar ama profundamente a Igreja - como a um corpo mesmo: único, orgânico, pleno de vida, ligadura, nervos,..., mas não tão pleno ou saudável em todas as suas partes. Tais partes doentes não comprometem a plenitude de vida que circula por todo o corpo eclesial - embora o façam sofrer e gemer, pois, se um membro sofre, todo o corpo sofre com (por) ele (1 Cor 12,26a).

\footnotetext{
${ }^{7}$ Cf. idem. Vraie et fausse reforme dans l'Église. Ob. cit. P. 18.

${ }^{8}$ Cf. idem. À mes frères. Collection Foi Vivante, 71. Paris. Les Éditions du Cerf. 1968. P. 28.

${ }^{9} \mathrm{Cf}$. MORAES, Eva. Odres novos para um vinho novo: a eclesiologia de comunhão de Ives Marie-Joseph Congar Tese Doutoral defendida na PUC-Rio. Março de 2004. Passim.

${ }^{10}$ Cf. CONGAR, Yves. El Espiritu Santo. Ob. cit. P. 201.

${ }^{11}$ Cf. ibidem. P. 51; 52.
} 


\section{Os elementos constitutivos da eclesiologia de comunhão de Yves Congar}

Os pressupostos básicos - dentre os diversos que este autor desenvolve - para a eclesiologia de comunhão de Congar, são as suas cristologia e pneumatologia, intrinsecamente articuladas, a ponto de serem o que a teologia denomina cristologia-pneumatológica e pneumatologia-cristológica, em plena interdependência. A pessoa, a vida, a ação e a ressurreição de Cristo se dão no e pelo Espírito; do mesmo modo, a ação do Espírito se dá em função do Cristo. E como tudo o que o Cristo é e faz, Ele o é e Ele o faz em função do Pai, para agradar ao Pai, dar-lhe louvor e glória, inaugurar em Si mesmo o Reino do Pai, então, temos, aqui, um laço inexorável entre as Pessoas trinitárias, revelado, exatamente, pela profunda interconexão entre o Verbo e o Espírito, na pessoa de Jesus de Nazaré.

A revelação deste entrelaço fundamental dá-se, eminentemente, no dado bíblico, anteriormente a qualquer reflexão metafísica - um método que Congar compreendeu e refletiu profundamente em suas obras. Tal articulação se nos revela como fundação e base de toda teologia e, portanto, de qualquer eclesiologia, principalmente a de comunhão. Antes de ser uma necessidade, tal articulação intrínseca é uma realidade, advinda da própria Revelação, desde os textos bíblicos, passando pela Tradição, chegando-nos aos dias de hoje. Congar nos revela essa percepção e é fiel a ela.

Os enunciados das obras de nosso autor possuem um profundo caráter cristológico $e$ pneumatológico: sem cessar, expõem o Cristo como o princípio que contém tudo, e, o Santo-Espírito, como o agente que coopera com o organismo apostólico da Igreja para efetuar dinamicamente no mundo o mistério de $\mathrm{Cristo}^{12}$. Para ele, uma pneumatologia, para ser plena, deve ser cristológica, ou seja, que não separe a ação do Espírito da obra de Cristo: ambos realizam a atualidade na vida da Igreja, segundo a imensa variedade de suas formas, através dos espaços e dos tempos ${ }^{13}$. Da mesma forma, a única cristologia que podemos defender é pneumatológica.

Congar sabe que a junção entre cristologia e pneumatologia não é recente, pois recorda-nos que, no ambiente da filosofia estóica, via-se o pneu$m a$ como força que penetrava o universo e mantinha-o em conjunção, de modo que se associava ao logos, ao qual atribuíam também uma função cósmica, anterior a seu papel na economia da salvação. Também os Padres: colocaram no nascimento de Jesus o começo da nova criação - uma criação, ao mesmo tempo, pascal e pentecostal. Nestas pegadas, seguiu a reflexão do

${ }^{12}$ Cf. idem. Cette Église que j'aime. Les Éditions du Cerf. Paris. 1968. P. 43.

${ }^{13}$ Cf. idem. El Espiritu Santo. Ob. cit. P. 188. 
Concílio Vaticano II: manteve a referência cristológica, que é bíblica, e a pneumatológica.

Entre a missão ou obra do Espírito Santo e a missão ou obra do Cristo, há, antes de tudo, homogeneidade de finalidade e de conteúdo ${ }^{14}$. A obra do Espírito é a própria obra do Cristo: sua função é lembrar tudo o quanto o Cristo disse (cf. Jo 14,26; comparar com 16,12s), dar testemunho de Jesus (cf. 1Jo 4,1s; Jo 15,26; Ap 19,10; At 1,8). O que o Espírito opera em nós é exatamente o que Jesus operou - é por isso que as Escrituras referem tantas vezes as operações espirituais, indiferentemente, ao Cristo (ao Senhor) ou ao Espírito Santo (cf. Jo 14,18s; 16,16.22.25; 2Cor 3,17.18).

Todos os que afirmam uma equivalência de ação entre o Cristo e o Espírito não podem explicar-se, na ótica de Congar, a não ser por um recurso à mais profunda teologia trinitária, com as noções de consubstancialidade perfeita das Pessoas divinas, de circumincessão e de pericorese (o grego $\pi \varepsilon \rho \imath \chi \omega \rho \varepsilon \omega)$. Portanto, Congar apresenta-nos, freqüentemente, a Cristologia unida à Pneumatologia, e vice-versa, tornando-se impossível separá-las, mesmo que servindo a uma intenção metodológica. Apesar disto, foi o que tentamos fazer.

\section{1 - A cristologia-pneumatológica}

Como pecadores, não encontraremos a Deus senão no Cristo. Não somos nós que nos apoderamos de Sua santidade, ou representamos os gestos de sua vida filial: é Ele que, vindo até nós, continua na humanidade o gesto de amor e de louvor para com o Pai, que Ele cumpriu antes aqui em baixo, ao mesmo tempo como Deus e como um de nós, em nome de todos nós. É Ele que, tendo-se tornado homem para que todos nós chegássemos a ser Deus, opera não somente sua encarnação, mas, também, nossa divinização ${ }^{15}$. È uma vida divina que Ele nos dá para vivermos em nossa carne, pela graça d'Ele, assim sendo que a força do Espírito Santo não é somente geradora do Cristo no seio de Maria, mas, também, dos cristãos no seio da Igreja. Congar dá uma base séria à grande poética de Teilhard de Chardin ${ }^{16}$, que situa o fracasso e o mal na visão de um universo em caminho de ordem e de subida, por convergência, para um ponto de plenitude.

Para Congar, os evangelhos começam não com a encarnação de Jesus, mas com a chamada de João Batista à conversão e com o batismo de Jesus

\footnotetext{
${ }^{14}$ Cf. idem. Introdução ao Mistério da Igreja. Editora Herder. São Paulo. 1966. P. 108-110.

${ }^{15}$ Cf. ibidem. P. 76-77.

${ }^{16}$ Cf. ibidem P. 138.
} 
pelo mesmo (cf. Mc 1,1ss) ${ }^{17}$. Segundo esse autor, antes da Encarnação do Verbo em Jesus, houve numerosos dons de luz e de graça, dados individualmente às pessoas, a partir de sua resposta moral pessoal - a salvação que está em Deus jamais faltou aos seres humanos ${ }^{18} \ldots$ Entretanto, foi $n$ 'Ele, realmente, que a vontade universal de salvação tomou a forma de uma realidade concreta e compreensível, designável. Não mais somente aquela de uma realidade transcendente, supra-histórica, disseminada de modo secreto nas vidas individuais, mas uma forma humana, histórica.

Nos diz Congar que a individualidade humana Jesus, suscitada no seio de Maria pelo Espírito, é, no mesmo instante, assumida pelo Verbo-Filho, e começa a existir pela pessoa do Filho ${ }^{19}$. Notamos, aqui, uma clara e surpreende cristologia ascendente, que soa às vezes incômoda aos nossos ouvidos acostumados a uma cristologia descendente. Como Congar apresenta essa cristologia trabalhada pelo Espírito, não é o Verbo que "desce" em Jesus, mas é a "carne" de Jesus que é assumida pelo Verbo. Assumir, em português, pode significar tomar sobre si, encarregar-se de, entrar no exercício de. Para Paulo, a encarnação (cf. Fl 2,5-12) é, sobretudo, a perfeita aceitação da condição humana, em toda sua grandeza, mas, também, em toda sua miserabilidade; e, a condição divina é sentida no fato de que a identidade de Jesus Cristo não se reduz à sua humanidade, mas que transcende perfeitamente a miserabilidade humana ${ }^{20}$. Para Paulo, a kênose do Verbo em Jesus não significa, a priori, a carnalização do Verbo, mas ter assumido a condição de doulos, de escravo. A pré-existência é tema essencial da eclesiologia joanina (cf. Jo $1,1.15 .18 .30 ; 6,62 ; 8,58 ; 17,5.25)$. A palavra joanina carne busca frisar o aspecto terrestre, limitado, perecível, em contraste com a natureza celeste, eterna, do logos - uma oposição que já era veterotestamentária (cf. Gn 6,3; Is 31,$3 ; \mathrm{Jr}$ 17,5; S1 78,39; etc). Segundo Jo 1,14, a encarnação é um vir morar, armar a tenda, como no caso da Sabedoria (cf. Eclo 24,8) -a finalidade da encarnação é que o Filho transmita os bens salvíficos do Pai aos fiéis.

Portanto, não se trata de uma simples teofania, mas da realidade pessoal e substancial do Verbo feito carne. É certo, diz Congar, que Jesus era Filho de Deus e estava habitado pelo Espírito desde o seio de Maria, mas os evangelistas operam com a pneumatologia herdada do Antigo Testamento (AT) e do judaísmo (o Espírito Santo é o espírito, o sopro poderoso, criador e vivificante de Deus, e a força pela qual Jesus opera milagres, expulsa de-

\footnotetext{
${ }^{17}$ Cf. idem. El Espíritu Santo. Ob. cit. P. 41.

${ }^{18}$ Cf. idem. À mes frères. Ob. cit. P. 35-36.

${ }^{19}$ Cf. idem. El Espiritu Santo. Ob. cit. P. 211.

${ }^{20}$ Cf. BORN, A. V. Dicionário Enciclopédico da Bíblia. Petrópolis. Ed. Vozes. 1985. P. $451 \mathrm{~s}$.
} 
mônios - cf. At 10,38s; Mt 12,28; Lc 11,20). Jesus tem o Espírito e O tem por um ato de Deus, que expressa seu amor e gera uma união correspondente com Ele $^{21}$. Um primeiro envio do Espírito constituiu santo e Filho de Deus (= Messias) a este ser suscitado em Maria.

Portanto, as relações entre a Mãe de Deus, Jesus Cristo, e o Espírito Santo são profundas - derivam mesmo do mistério de salvação. Nosso autor afirma que, no anúncio a Maria, Palavra e Espírito vêm juntos (cf. Lc $1,35)^{22}$. A função de Maria situa-se na função do Espírito Santo, que a fez mãe do Verbo encarnado. Outro laço fundamental é entre mariologia, cristologia, pneumatologia e eclesiologia, pois, no mistério cristão, Maria possui, de maneira supereminente, a posição de modelo da Igreja e de intercessão universal - esta é, nela, a obra do Espírito Santo. Portanto, para Congar, Maria exerce um papel importante na Igreja de Comunhão: pelo fato da comunhão de Cristo ser acompanhada com uma recordação Mariana e por Maria ser a mulher associada à ação soberana do Espírito. Jesus é Emanuel, o Deus conosco, porque é (concebido) do Espírito Santo - tal é teológica e dogmaticamente, o sentido de Lc 1,35. Segundo Congar, pela união hipostática, o Verbo é o princípio de existência de Jesus e sujeito metafísico de atribuição de seus atos, mas deixa à sua verdadeira e plena humanidade o jogo de suas faculdades de conhecimento e de vontade ${ }^{23}$.

Fl 2,6-11 é um dos textos mais conhecidos da cristologia. As anáforas orientais (São Basílio, São Gregório de Nazianzo, Teodoro de Mopsuéstia, Jean de Bosra) e a catequese dos Padres gregos - segundo Congar - vêem nesse texto bíblico o enunciado sintético do mistério da Encarnação, que, redentora, é, essencialmente, kênose ${ }^{24}$. Alguns exegetas vêem no texto uma alusão ao comportamento do primeiro Adão, que existe na condição de homem e quis gozar de uma condição de Deus (entendida como independência, afirmação de si, não limitada por nada e por ninguém - cf. Gn 3,5.22): querendo ser como Deus, caiu numa condição de nudez (cf. Gn 3,11), ou seja, de vida penosa e sujeita aos sentidos, enquanto que Jesus fez o caminho inverso (sendo Deus, quis ser um de nós).

A kênose encarnatória de Jesus, no trabalho do Espírito e em obediência ao Pai, $\mathrm{O}$ acompanha em toda a sua existência. Um dos momentos mais fortemente evidentes desta kênose é o lava-pés, onde a ordem é a de sermos seus seguidores, lavando-nos os pés uns dos outros; Congar vê neste fato

\footnotetext{
${ }^{21}$ Cf. CONGAR, Yves. A mes frères. Ob. cit. P. 42-43.

${ }^{22}$ Cf. ibidem. P. 44; 193.

${ }^{23}$ Cf. ibidem. P. 45.

${ }^{24}$ Cf. idem. "Dum visibiliter Deum sognoscimus". In: Les voies du Dieu vivant. Paris. 1962. P. 79-108. Apud idem. Igreja serva e pobre. Ob. cit. P. 22; nota ${ }^{\circ} 9$ da p. 23.
} 
como que uma ordenação ${ }^{25}$. O Plano do Pai é Se comunicar (cf. 1 Jo 1,1-3): segundo nosso autor, a realidade do alto deve, em patamares sucessivos, existir numa forma de baixo - e do mais baixo, de doulos, escravo -, que deve reproduzir o comportamento da Realidade-Fonte. Congar percebe uma correspondência entre a ordem do lava-pés (que ele chama ordenação) e a ordem da última ceia: fazei isto em memória de mim, e, fazei como fiz convosco.

Fazendo-se humano, o mistério do Filho do Homem se reflete em todo humano. Congar crê que esta estrutura da Economia positiva da salvação é preparada já na estrutura criacional das coisas: conseqüentemente, cada ser humano é uma realidade diante da qual devemos nos situar pelo amor - na presença de cada pessoa, se pré-forma nossa atitude em face de Deus mes$\mathrm{mo}^{26}$. Congar frisa que existiram e existem dons de luz e de graça trabalhando pela salvação fora dos limites visíveis da Igreja: eles devem ser recebidos pela Igreja, em vista da Igreja, para a Igreja e devem se incorporar $n a$ Igreja, mesmo que invisivelmente. Porque, em Jesus, o propósito de graça de Deus tomou uma forma sensível, visível, corporal - segundo Congar, pública, no sentido mais forte da palavra. Se a Graça feita a nosso mundo, em sua universalidade e de modo definitivo, veio por Jesus Cristo (cf. Jo 1,17), ela entrou para sempre no mundo sob uma forma corporal; e, com efeito, depois de Jesus Cristo e em virtude do que Ele fez, ela habita seu corpo eclesial ou comunional.

Segundo Congar, ao Se unir à natureza humana no Cristo, Deus tomou partido para realizar Seu desígnio. Ele, de modo definitivo e irreversível, começou o processo de adiantamento da criação, que deve se completar quando nos assimilarmos à Sua glória. O Cristo é esta figura posta na publicidade da história, de maneira humilde e não brilhante. Jesus Cristo é o elo perfeito entre Deus e a criatura. Nele, se realizam os anúncios messiânicos (cf. Mq 5,4: Is 42,6). Substancialmente, pela realidade da união hipostática, Cristo possui a graça segundo sua plenitude absoluta. Esta graça santifica perfeitamente nosso Mediador, homo Christus Iesus, que é também a aliança para o mundo na e por sua atividade perfeita de Homem-Deus: desde o momento quando uma alma humana foi unida à Pessoa do Filho de Deus, um coração perfeitamente filial bateu por Deus no mundo. Nosso teólogo confirma-nos que, desde o dia quando a segunda Pessoa da Santíssima Trindade fez-Se carne no seio de Maria pela ação do Espírito Santo, passou a existir no mundo uma consciência e uma liberdade humanas abertas e oferecidas ao Pai, para que a Sua vontade de salvação pudesse realizar-se perfeitamente.

\footnotetext{
${ }^{25}$ Cf. ibidem. P. $27 \mathrm{~s}$.

${ }^{26}$ Cf. idem. Cette église que j'aime. Ob. cit. P. 56-58.
} 
Em Jesus, o mundo teve, no Homem-Deus Jesus Cristo, seu centro ou seu cume de oração, adoração, desejo de comunhão ao Mistério de Deus, ação de graças...

Percebemos a importância que Congar dedica ao tema do batismo de Jesus, principalmente se ligado à eclesiologia; decepciona-se com o pouco peso teológico que a Tradição lhe deu, o oposto feito com o da encarnação. Recorda-nos que Santo Tomás, um dos que mais sistematizaram a ligação entre cristologia e pneumatologia, alimentou-a dos Padres gregos, de Agostinho, da primeira escolástica - fontes que foram a base da renovação teológica do século XIX, com Möhler, a escola romana e Scheeben, que colocam a Igreja em relação com a encarnação e a Trindade, em virtude da união hipostática ${ }^{27}$.

Nosso autor afirma que é preciso conceder a máxima importância à unção de Cristo pelo Espírito no momento do batismo, quando o Pai unge, o Filho é ungido e, o Espírito Santo, é a própria unção (cf. Lc 4,18, referindose a Is 61,1). Nosso teólogo afirma que, antes do batismo, Jesus não aparece atuando pela forç̧a do Espírito (cf. Lc 4,22; Mt 13,54-56; Mc 6,1s) ${ }^{28}$. Assim, o batismo de Jesus inaugura um novo capitulo: Jesus estava habitado e santificado pelo Espírito Santo desde sua concepção, e foi ungido pelo mesmo no momento de seu batismo para ser Messias (= missão) ${ }^{29}$. A tradição patrística e teológica, seguindo o NT, considera a união hipostática como uma consagração da humanidade de Jesus pela divindade, ou seja, não há uma unção de Cristo no momento da encarnação, mas no momento de seu batismo quando Padres como Metodio de Filipo, Atanásio, Gregório Nazianzeno, Gregório de Nissa, Agostinho, Cirilo de Alexandria afirmam o contrário, deve-se ver o contexto de seus escritos, a saber: a luta contra o arianismo ${ }^{30}$.

No batismo de Jesus, leva-se a cabo uma nova missão ou comunicação do Espírito $^{31}$ : Jesus é constituído, é declarado como Messias, sobre quem repousa o Espírito; Jesus é quem obrará pelo Espírito, e quem, glorificado e constituído Senhor, dará o Espírito. Jesus, em seu batismo, é consagrado para o ministério profético e, somente quando for exaltado à direita de Deus, poderá derramar o Espírito (cf. At 2,33). Congar recorda-nos que o batismo de Jesus foi o momento decisivo que inaugurou a missão que devia realizar por nós ${ }^{32}$. Por ter sido batizado no Espírito e por ter vencido o tenta-

\footnotetext{
${ }^{27}$ Cf. idem. El Espíritu Santo. Ob. cit. P. 52.

${ }^{28}$ Cf. ibidem. P. 41-42, nota $\mathrm{n}^{\circ} 1$ da p. 29.

${ }^{29}$ Cf. ibidem. P. 42, inclusive nota $\mathrm{n}^{\mathrm{o}} 2$.

${ }^{30}$ Cf. ibidem. P. 50-51, inclusive nota $\mathrm{n}^{\circ} 33$ da p. 50.

${ }^{31}$ Cf. ibidem. P. 43.

${ }^{32}$ Cf. ibidem. P. 51; 41-48.
} 
dor no Espirito, Jesus $\mathrm{O}$ experimenta ativo em si: faz presente o Reino de Deus, elimina (conseqüentemente) o demônio, cura a muitos (cf. Mt 8,17; Is $53,4 ; 12,15-21 ; 42,1-4), \ldots$

A descida do Espírito Santo sobre Jesus, imediatamente depois do batismo, é-nos apresentada como uma unção real e profética para seu ministério messiânico, a realização de uma libertação do mal e do maligno. Congar destaca, ao nome próprio de Jesus, seu valor bíblico de ungido, que, em hebraico, significa Messias - termo que conota as três funções de rei, sacerdote e profeta. A pregação dos apóstolos e a confissão da fé dos discípulos e das discípulas possuem como núcleo a afirmação de que Jesus é o Cristo, o Messias de Deus, que o ungiu - cf. At 10,37-38) ${ }^{33}$. Assim, o batismo de Jesus não é uma unção qualquer, mas em vista de uma missão e um ministério - missão declarada no momento do batismo, motivo pelo qual se pode afirmar que Jesus está destinado a ela desde o princípio.

A primeira vinda do Espírito, sua primeira união com uma energia humana que cooperou com Ele, operou a própria concepção de Jesus, no seio de Maria ${ }^{34}$. Mas, se esta é a primeira e decisiva vinda de Jesus Cristo entre nós, sua entrada messiânica propriamente dita, deu-se no batismo de Jesus por João (cf. At 1,21) - o próprio Jesus e seus discípulos chamam este batismo de o começo (cf. Jo 15,27; Lc 1,2; 3,23; At 10,37). Jesus, santificado desde a sua concepção (cf. Lc 1,35), o é em vista de seu ministério, que é assumido em seu batismo messiânico. É por isso que Ele é, pela segunda vez, chamado Filho, e Ele será chamado assim pela terceira vez no mistério de sua passagem (morte-ressurreição-ascensão - cf. At 13,33), como se Ele fosse enviado ao mundo, pela segunda vez.

O Verbo esposou, em sua Encarnação, a natureza humana, segundo o ser e segundo a vida, para existir humanamente conosco; no seu batismo, Ele esposa a Igreja - suas bodas consumar-se-ão no mistério de sua Páscoa, pela qual os sacramentos e toda obra do ministério receberão a eficiência - Ele esposa a Igreja, corpo visível dos meios da graça e que se constitui como tal a partir do batismo. Jesus é constituído Filho de Deus na hora de sua concepção, mas é declarado Filho de Deus na hora de seu batismo: Ele se torna Filho para nós neste momento, em que é instituído o batismo de Espírito, o de nossa própria filiação - é o começo da ordem sacramental, do ministério, e da associação do Espírito Santo com Jesus e conosco.

Jesus viveu sua missão desde a infância até à cruz sob o regime da obediência (cf. Fl 2,6-8; Rm 5,19)52. Vimos, anteriormente, que todo o relato

\footnotetext{
${ }^{33}$ Cf. ibidem. P. 53-54.

${ }^{34}$ Cf. o símbolo de Nicéia-Constantinopla. Denzinger, no ${ }^{\circ}$ 86. Cf. 1,35. INÁCIO DE ANTIOQUIA, Ef 18,2. Apud idem. Introdução ao Mistério da Igreja, ob. cit. P. 128-129.
} 
do batismo de Jesus representa um momento decisivo na explicação da consciência que Ele teve, em sua alma humana, de sua qualidade de eleito, enviado, Filho de Deus e Servo-cordeiro de Deus. Jesus compreendeu sua missão exercendo-a - de um lado, descobrindo-a na lei de Moisés, nos profetas, nos salmos; de outro, recebendo do Pai as obras maravilhosas e as palavras proféticas; vivendo, na obediência, a vontade de Deus sobre ele. Congar segue Mt 3,15, que diz que Jesus veio ao batismo e viveu o acontecimento na disposição de oferecer-Se e abrir-Se a todo o plano que Deus tinha para ele, que passava pelo tipo do Servo, com a oferenda suprema da vida (cf. $\mathrm{Hb}$ 10,5-10).

Igualmente, Jesus viu sua morte como um batismo (cf. Mc 10,38; Lc 12,50); ofereceu-Se a Deus, pelo Espírito, como vítima - seu sacrifício foi a continuação de seu batismo e, a glória, a conseqüencia de seu batismo. $\mathrm{Na}$ mesma seqüência teológica, Congar revela-nos que Cristo transmite a seus apóstolos a assistência do Espírito que Ele recebeu no Jordão ${ }^{35}$ - portanto, percebemos uma íntima relação entre cristologia, eclesiologia e pneumatologia, bem como uma também estreita articulação entre o batismo de Cristo no Espírito e o nascimento da Igreja no Espírito, tendo como elo a ressurreição de Cristo pelo Pai no Espírito.

Temos, em Jesus, a redenção (cf. 2Cor 5,14-15.18-19; etc) de todas as coisas (cf. 1Cor 1,30; Ef 1,7s). Nos reconciliamos com Deus n'Ele, e isto se dá porque Ele é o princípio de toda nova ordem de coisas ${ }^{36}$. São Paulo exprime esta idéia de duas maneiras: pela noção de cabeça (cf. Ef 1,22-23; 4,15-16; 5,22s; Col 1,18; 2,10.1955) e pela idéia de segundo Adão (cf. 1Cor 15,21-22; 44-50; comparar com Rm 5,14). Congar nota, aqui, uma perfeita equivalência entre a nova ordem de coisas das quais o Cristo é o princípio e o Reino do Pai. Ele chegou a ser isto na cruz, ou seja, pelo meio de sua paixão-ressurreição-ascensão.

Congar detém-se em algo sumamente importante, na questão da ressurreição de Jesus: a dimensão kenótica aí presente. Ou seja: a kênose do Verbo não se fez presente apenas em sua encarnação, vida e morte, mas, igualmente, em sua glória - que é uma glória kenótica, despojada. Nosso autor reflete que Jesus possui tal dignidade gloriosa por causa da missão que recebera do Pai: possui tal glória porque fez a vontade do Pai e realizou integralmente a missão a que fôra enviado (cf. Jo 5,39-44; 7,16-18; 8,54) ${ }^{37}$. A glória de Jesus é junto do Pai e, não, dos seres humanos.

${ }^{35}$ Cf. idem. El Espiritu Santo. Ob. cit. P. 72.

${ }^{36} \mathrm{Cf}$. idem. Introdução ao mistério da Igreja. Ob. cit. P. 15-16.

${ }^{37}$ Cf. idem. Igreja serva e pobre. Ob. cit. P. 18-19. 
Como pudemos observar, após o batismo, Jesus assume sua missão, definindo-a e vivendo-a em termos de Servo, segundo Isaías (cf. 4,1): viveu a condição de escravo, até aquele ponto verdadeiramente específico de ser vendido, de fazer a si mesmo o preço do resgate ${ }^{38}$. Como vimos na reflexão sobre a encarnação, Jesus Cristo fez o caminho inverso de Adão: existindo na condição de Deus, não teve um comportamento possessivo, mas assumiu livremente a condição de escravo; não quis reinar soberanamente sobre o mundo e não reivindicou este direito em espírito de aquisição, mas quis obtêlo de Deus por um serviço humilde, abaixando-se a si mesmo em Espírito de amor - enquanto Adão, querendo exaltar-se, caiu, Cristo, abaixando-se, foi exaltado com a ressurreição.

Nosso autor cita Santo Tomás de Aquino, segundo o qual tudo o que o Cristo faz ou sofre na carne por nossa salvação, preserva, em sua existência gloriosa, uma virtude que causa (ou causará) instrumentalmente em nós (em nossa humanidade) os efeitos correspondentes ${ }^{39}$. São João testemunha que Jesus e seus discípulos tinham o Espírito, mas a doação do Espírito dos tempos messiânicos foi realizada por Jesus glorificado, elevado à condição de Senhor. É uma doação diferente do mesmo Espírito, derramado desde sempre sobre a criação, mas, agora, acrescido de um novo dom: a nossa humanidade ressurreta no corpo glorioso de Jesus. A glorificação de Jesus como Senhor condiciona o envio do Espírito, por parte de Jesus, e consiste em que sua glória de Filho seja comunicada à sua humanidade, oferecida e imola$\mathrm{da}^{40}$.

No Novo Testamento (NT), Jesus diz: O Pai que mora em mim é quem realiza suas obras (Jo 14,10) - portanto, Deus é o Pai de Jesus ${ }^{41}$. Em Jesus, Deus encontra uma vontade e um coração humanos comungando perfeitamente a Sua vontade: um destino de salvação, envolvendo e englobando toda a história humana ${ }^{42}$. Destaca nosso autor que este é um tema que possui um valor dogmático decisivo: o plano de Deus é de ter constituído em Jesus a realidade perfeita da relação filial do humano com Ele, e de fazer participar toda a humanidade nesta realidade, de modo que todos possam, em Jesus Cristo, dizer unanimemente nosso Pai.

Todos os evangelhos falam do tema da missão do Filho por parte do Pai, mas o de João, segundo Congar, insiste mais neste ato e o coloca na

\footnotetext{
${ }^{38}$ Cf. Nota da Bíblia de Jerusalém sobre Is 4,1. Apud ibidem. P. 22s.

${ }^{39}$ Cf. TOMÁS DE AQUINO. II a II xe , q. 83, art. 167. In I Tim, c. 2, lect. 1. Apud idem. Cette Église que j'aime. Ob. cit. P. 113. Cf. idem. El Espíritu Santo. Ob. cit. P. 113.

${ }^{40}$ Cf. idem. El Espíritu Santo. Ob. cit. P. 79.

${ }^{41}$ Cf. RAHNER, K. "Theos en el Nuevo Testamento". In: Escritos de Teologia, t. I. Madri. Taurus. 1967. P. 93-166. Apud ibidem. Nota ${ }^{\circ} 5$ da p. 42.

${ }^{42}$ Cf. ibidem. P.107-108.
} 
boca de Jesus (cf. 10,40; Mc 9,37; 12,6; Lc 9,48; 10,16; Jo 3,17.34; 5,37; $6,57 ; 7,28 ; 8,42 ; 10,36 ; 17,18 ; 20,21)^{43}$. Em sua missão, Jesus está investido no mesmo poder do Pai, que colocou tudo em suas mãos (cf. Jo 3,$35 ; 13,13$ ) - mas é uma autoridade toda ordenada à nossa salvação, e por meio da maior humilhação; em segundo lugar, é uma autoridade inteiramente recebida do Pai, e, portanto, dependente d'Ele - dependência que Jesus reconhece (cf. Jo 7,$16 ; 5,30 ; 12,49 ;$ passim $)^{44}$.

Missão - diz Congar - implica uma referência à pessoa que envia (o $P a i$, que envia, mas não pode ser enviado) e uma referência também àqueles aos quais é enviado ${ }^{45}$. O Verbo de Deus começa, assim, a estar entre nós de uma forma nova, de como quando se estava anteriormente: o Verbo encontrava-se no mundo desde o começo deste (cf. Jo 1,10), mas vem a Jesus (cf. Jo 1,11.14) de uma forma nova e plena. Também o Espírito é enviado pelo Pai, mas é o Espírito de Seu Filho (cf. Gal 4,6). Porém, há uma diferença entre ambas as missões: a do Filho é uma missão visivel. O Verbo-Filho encarnado é expressão do ser de Deus Pai (cf. Hb 1,3) - é, verdadeiramente, uma apreciação humana de Deus.

É principalmente na oração que notamos a relação de Jesus com seu Pai. Sua oração revela o Seu desejo numa condição de submissão a um $O u$ tro: uma oração que é perfeitamente conforme ao desígnio de salvação que vem do Pai, com a universalidade com a qual ela (Sua oração) identifica$\mathrm{se}^{46}$. Congar nos diz que o Pai está em Jesus: o caminho que leva a Deus tudo em todos (1Cor 15,28) é um em que a vida irradia, a partir de Deus, sobre todos: é o caminho do humilde serviço de amor ${ }^{47}$. O Filho manifestou admiravelmente em seu comportamento o conhecimento que nos deu do Pai (cf. Jo 1,$18 ; 3,11.16 ; 14,1-11 ; 17,6)^{48}$.

O evangelista São João exprime a idéia de uma continuidade na cena do lava-pés: uma espécie de missão sucessiva do Pai ao Filho encarnado e do Filho encarnado aos Apóstolos e às discípulas, e, destes, para toda a Igreja. Congar, portanto, nos ajuda a perceber, pelas Escrituras, uma dinamicidade, um movimento de correspondência: o Filho como que "reproduz" (entre aspas, pois há diferença de naturezas) o que se dá na sua relação com o Pai e na do Pai consigo, na Sua relação com os seus. A expressão congariana usada - patamares sucessivos - poderia ser sinônimo de desdobramentos

\footnotetext{
${ }^{43}$ Cf. ibidem. P. 210.

${ }^{44}$ Cf. idem. Igreja serva e pobre. Ob. cit. P. 19.

${ }^{45}$ Cf. idem. El Espiritu Santo. Ob. cit. P. 210s.

${ }^{46}$ Cf. idem. Cette Église que j'aime. Ob. cit. P. 111.

${ }^{47}$ Cf. idem. Igreja serva e pobre. Ob. cit. P. $25 \mathrm{~s}$.

${ }^{48}$ Cf. ibidem. P. 27-28. Idem Introduçao ao Mistério da Igreja. Ob. cit. P. 29.
} 
sucessivos: a própria Revelação de Deus vindo a nós, revelando-Se em nossa cultura humana de forma sucessiva, gradativamente, até o ápice da autocomunicação de Deus, na união hipostática do Verbo com o homem Jesus de Nazaré.

O caminho de Cristo é o caminho de Deus - isto é, do Pai (cf. Ef $5,1.25)^{49}$. As Escrituras revelam de que o movimento de amor humilde e servidor começa no seio do Pai (cf. 2Cor 5,19; Jo 3,16; 1Jo 4,10). A missão da Igreja é fazer com que todos os seres humanos possam invocar o Deus e Pai de Jesus Cristo e dizer, n'Ele: nosso Pai ${ }^{50}$ ! Tocamos aqui a estrutura profunda de toda a obra de Deus, dominada por um ideal de comunhão de muitos na unidade. Deus fez a humanidade una e seu plano de redenção é de refazê-la una no Cristo por seu Espírito. Aqui, protogênese e escatologia se encontram: o começo e o fim se co-respondem; biblicamente falando, o termo é visto desde o início, onde ele é colocado em estado de gérmen, e o fim revela e, ao mesmo tempo, realiza a verdade de cada ser, visto desde seu começo. Somente na escatologia será esboçada a unidade querida por Deus e restaurada pelo Cristo, e se poderá dizer: tudo está feito, o homem está feito ${ }^{51}$ - quando o humano restituirá a Deus sua imagem, como filho a seu Pai, pronunciando plural e unanimemente: Nosso Pai!

Em Jesus Cristo, Deus se engajou total e definitivamente pelo ser humano e pelo mundo ${ }^{52}$. Cristo não abandonou sensivelmente esta terra, mas enviou seu Espírito como continuação de sua própria missão. A Igreja vem depois dele, pela virtude de sua própria missão e da do Espírito Santo, que opera nela. A Igreja é um sacramento visível, comum, público e de valor universal, da salvação que está em Jesus Cristo. Se o Cristo forma, como segundo Adão e como cabeça, o princípio da nova ordem de coisas (que é a Igreja), então isto acontece porque Ele tem, em Si, a plenitude das realidades e das potências divinas ${ }^{53}$. Como nos revela São Paulo e recorda-nos Congar, se ele é cabeça, então é porque Ele é pleroma (cf. Col 1,18-19); e, porque n'Ele habita a causa da plenitude do ser divino, Ele é, para a humanidade e para toda a criação, um princípio de renovação e de comunicação de vida divina (cf. Ef 1,23; 3,19; 4,12s; Col 1,18-20; 2,9s; etc). Assim, recebendo do Cristo nova vida (como o corpo a recebe da cabeça), todas as coisas são, n'Ele, recapituladas. O Cristo possui uma realeza total, cujo exercício inte-

\footnotetext{
${ }^{49}$ Cf. ibidem. P.26.

${ }^{50}$ Cf. idem. À mes frères. Ob. cit. P. 33-35.

${ }^{51}$ Cf. TENNYSÓN. "The Making of Man”. In: The Death of Oneone and other Poems. 1982. Apud ibidem. P. 34. Idem. Sainte Église. Paris. 1963. P. 172-173.

${ }^{52} \mathrm{Cf}$. idem. À mes frères. Ob. cit. P. 36, e nota $\mathrm{n}^{\circ} 36$.

${ }^{53} \mathrm{Cf}$. idem. Introdução ao mistério da Igreja. Ob. cit. P. 16-17.
} 
gral tem por efeito o Reino - isto é: o empreendimento pleno do Espírito de Deus sobre todas as coisas, respeitando a liberdade das criaturas ${ }^{54}$.

Congar destaca que é preciso superar a idéia de uma pura salvação de almas individuais - como de alguns que são salvos de um naufrágio, onde todo o resto pereceu. Para ele, esta representação não dá conta nem da situação e do papel do humano no mundo, nem da unidade do plano de Deus e de sua obra, nem dos testemunhos da Escritura sobre o caráter cósmico da Redenção ${ }^{55}$. Essa redenção cósmica, a nosso ver, refere-se à comunhão: ele liga a salvação para além de almas individuais, como vimos, e para além do comunitário. Portanto, Congar afirma o laço entre o homem e o cosmo, e a unidade destes, que é o universo; destaca que o todo criado é feito de um único material e que a pessoa humana participa psiquicamente neste material, apesar de transcender o mundo pela consciência pessoal. No humano, o universo alcança a dignidade hipostática ou pessoal; por sua vez, o ser humano, ligado ao mundo, o transforma. Assim, a união entre os dois é tal que, no e pelo humano, o cosmo chega a seu fim; é uma união no destino, fundado, ao mesmo tempo, na unidade do propósito de Deus em suas comunicações ad extra e na unidade real do universo.

Segundo Congar, a história da salvação é mais importante que a história da Revelação e da instituição positiva da aliança (esta começa com Abraão mil e oitocentos anos antes de Cristo: pouco tempo, em proporção ao extensivo da história humana) ${ }^{56}$. Para Congar, trata-se de uma teologia da história: a história avança - seja na escala de nossas vidas pessoais, seja na escala coletiva - por iniciativas ou começos que, uma vez colocados na trama do tempo, mudam tudo o que existe ${ }^{57}$. Congar alerta-nos que também na história coletiva da Salvação: o que foram e fizeram Moisés, Davi, Paulo de Tarso, Agostinho, Vicente de Paula, os santos fundadores, estão ainda presentes e vivos entre nós.

Tratando-se de Jesus Cristo, Congar relata-nos que acontece o mesmo, mas num plano novo: o de uma eficácia: Ele veio como segundo Adão, homem escatológico (escathos Adam - cf. 1 Cor 15,45), sendo um humano de submissão e de ação de graças - um humano de comunhão, de adesão a Deus nos outros, um humano do Deus tudo em todos (1 Cor 15,28) ${ }^{58}$. O último Adão é um Espirito que dá a vida (1 Cor 15,45); o primeiro Adão vive, mas de uma vida que está, permanentemente, em perigo de se perder. Deus será

\footnotetext{
${ }^{54}$ Cf. idem. À mes frères. Ob. cit. P. 47-48.

${ }^{55}$ Cf. idem. Cette Église que j'aime. Ob. cit. P. 46s.

${ }^{56}$ Cf. ibidem. Nota ${ }^{\circ} 14$ da p. 55.

${ }^{57}$ Cf. ibidem. P. 112.

${ }^{58}$ Cf. idem. Igreja serva e pobre. Ob. cit. P. 24-25.
} 
tudo em todos (1Cor 15,28), por Cristo (1 Cor 15,22) - contudo, Cristo não deixará só para o fim esse objetivo, pois iniciou-o com a sua vida mortal, na carne. Isto é: o caminho revelado por Ele é igual ao termo, e somente se chega ao termo quando tudo tiver voltado ao seu Princípio (cf. Jo 14,1-11) ${ }^{59}$. Tendo descido do céu, por nós, Ele voltará a subir conosco, nós voltaremos a subir para o céu n'Ele (cf. Ef 4,10). Nossa escatologia - engajada e assegurada pela Encarnação do Filho de Deus e pelo envio do Santo Espírito - não é somente de consumação da criação, mas uma absoluta comunhão com $\operatorname{Deus}^{60}$.

\section{2 - A pneumatologia-cristológica}

A pneumatologia é um item essencial da teologia - em conexão à Cristologia -, mas muitas vezes preterido ou mal elaborado; é tema fundamental para uma profunda espiritualidade e uma autêntica experiência de Deus e de Igreja Comunhão ${ }^{61}$. Ele afirma que, em sua relação com o Pai e o Filho, o Espírito é o Nós em pessoa - uma representação que não é válida somente para a Trindade essencial (intradivina), mas também para a econômica (a revelação das Pessoas divinas em benefício do mundo e dos seres humanos) $)^{62}$.

É o Espirito Santo quem funda uma comunhão entre Deus e nós, entre nós e Deus, e entre nós (cf. 2 Cor 13,13) ${ }^{63}$. Entendemos a fundamentação teológica para a vivência e a realidade da comunhão na Igreja como a trinitária - como afirmam a Tradição da Igreja e Congar. Assim Tertuliano expressa a unidade da Igreja:

\section{Porque ali onde estão os Três, Pai, Filho e Espirito Santo, ali também encontra-se a Igreja, que é o corpo dos Três ${ }^{64}$.}

Percebemos, porém, que nem sempre essa fundamentação esteve presente (ou presente de forma equilibrada) na vida da Igreja; entretanto, o Concílio Vaticano II fundamentou sua doutrina em uma visão trinitária da economia da criação e da graça - tanto no tocante ao princípio (plano do Pai, missão do Verbo- Filho, missão do Espirito Santo), quanto ao fim (Povo de

\footnotetext{
${ }^{59}$ Cf. idem. Introdução ao Mistério da Igreja. Ob. cit. P. 93.

${ }^{60}$ Cf. idem. À mes frères. Ob. cit. P. 36.

${ }^{61}$ Cf. idem. El Espiritu Santo. Ob. cit. P. 101.

${ }^{62}$ Cf. ibidem. Cf. nota $\mathrm{n}^{\circ} 49$ da p. 52; 54-55; 25.

${ }^{63}$ Cf. ibidem. P. 70

${ }^{64}$ De baptismo 6 (CSEL 20, p. 206), trad. F. REFOULÉ, SChr 35 (1952), p. 75. Apud ibidem. P. 207.
} 
Deus, Corpo de Cristo, Templo do Espírito Santo), segundo a admirável fórmula de São Cipriano, que inspirou a afirmação na qual a Igreja é apresentada como o:

\section{Povo que extrai sua unidade da unidade do Pai, do Filho e do Espirito Santo ${ }^{65}$.}

A missão do Espírito é a continuação, no tempo humano, de sua processão eterna do Pai e do Filho (a missão do Verbo é a união hipostática em Jesus, e, a do Espírito Santo, a formatio corporis e a santificação de Jesus). Congar, a partir daí, pergunta-nos se não deveríamos reconhecer tal seqüência na Igreja, visto que se deu primeiramente, a instituição dos Doze por Jesus (cf. Mc 3,14) - momento da formatio corporis da Igreja - e, depois, a santificação e a animação dos apóstolos pelo Espírito de Pentecostes - momento da santificação da Igreja -, embora entendamos que Congar não estabelece uma ruptura, mas apenas quer destacar as particularidades de ambas as Missões.

Nosso autor expõe dois valores, para ele, essenciais, em vista de uma teologia do Espírito nas Escrituras: uma certa personalização do Espírito ${ }^{66}$, e, a condução dos fiéis - e do próprio Messias - à realização do plano de Deus (cf. Is 32,15-17; 63,7-14; S1 143; Ne 9,20-21; Pr 20,27; etc). O ponto essencial é que, nas Escrituras, o ser humano encontra-se diante do Espírito como situado ante uma realidade que vem de Deus, mas sem ser idêntica a Ele: nosso autor percebe já nos dados do AT uma certa intuição acerca da Trindade - o Espírito Santo é uma realidade divina, enviada por Deus, e que atua com uma certa autonomia. A economia - ou Plano de Deus - do qual as Escrituras dão testemunho, progride no sentido de uma interioridade mais profunda - Deus tudo em todos.

Congar nos recorda que a revelação e o conhecimento do Espírito estão afetados por uma certa carência de mediações de ordem conceitual; portanto, é necessário nos perguntar pela experiência do Espírito ${ }^{67}$. Para falar do Pai e do Filho, dispomos de noções bem definidas e acessíveis, mas falamos da Terceira Pessoa em termos comuns e absolutos (Espírito, Santo, são conceitos que convêm tanto à terceira Pessoa trinitária, como também ao Pai e ao Filho; processão se aplica igualmente ao Verbo-Filho e ao Espírito,...). Neste sentido, Congar fala de uma espécie de kênose do Espírito Santo: Ele

\footnotetext{
${ }^{65}$ Ibidem.

${ }^{65} \mathrm{LG} \mathrm{n}^{\circ}$ 2-4. GS n ${ }^{\circ} 40$ § 2. $\mathrm{PO}$ n $^{\circ} 1$. AG n 7 $7 \S 3$ e 9, final. Apud ibidem. P. $197 ; 211$.

${ }^{66}$ Cf. ibidem. P. 38-40.

${ }^{67}$ Cf. ibidem. P. 15-16.
} 
se esvaziaria, de alguma maneira, de sua própria personalidade para ser todo relativo e ser a própria relação ${ }^{68}$. À diferença de Yahveh no AT, e de Jesus, no NT, o Espírito não empregou o pronome pessoal eu - exatamente porque, na trindade imanente, Ele é o Nós: Ele é tudo o que o Pai é e tudo o que o Filho é, ao mesmo tempo, sendo, portanto, um terceiro.

Entre nós, igualmente: o Espírito Santo não é um adendo, ou um ane$x o$ à revelação trazida pelo Filho: o Espírito Santo realmente habita entre nós e deixa, em nós, os sinais de Sua presença e Sua ação - contudo, nos alerta Congar, o Espírito Santo não está unido a estas realidades em existência e substancialmente: são apenas sinais, que podem resultar ambíguos ocasionalmente (cf. Atos 2,13). Congar relaciona o Espírito à Igreja: não entende a pneumatologia apenas como uma simples dogmática acerca da terceira Pessoa da Trindade ou, ainda, como uma exposição profunda da habitação e ação santificante do Espírito Santo nas almas ${ }^{69}$; ele compreende o impacto (dentro da visão que normalmente tem-se de Igreja) do fato de que o Espírito distribua nela seus dons como quer, e construa, dessa maneira, a Igreja - o que não apenas empenha uma consideração destes dons ou carismas, como também uma teologia da Igreja.

Nosso autor cita aquele que, para ele, é um dos maiores místicos cristãos: o oriental São Simeão (1022): chama-o de novo teólogo por ele ter feito e comunicado uma experiência nova de Deus ${ }^{70}$. Quem tem a graça do Espírito em seu coração, possui a Trindade habitando nele, iluminando-o e fazendo-o Deus ${ }^{71}$. Para Congar, além de Simeão, os doutores da fé da Igreja foram, freqüentemente, homens espirituais - como Santo Tomás de Aquino, de sua particular predileção. O cosmo ético do acontecimento do Espírito é o da vontade salvífica e santificadora de Deus, seguindo medidas que superam toda a racionalidade humana: é Deus quem nos guia, mas não sem nós.

Congar, contudo, discerne algumas experiências errôneas acerca do Espírito, comprovadas pela história, tanto no campo protestante como no católico $^{72}$. Neste último, por exemplo, cita a transposição errônea das funções do Espírito Santo a Maria, a quem nos dirigimos, geralmente, como consoladora, advogada, defensora dos fiéis ante Cristo; graças a ela, não somos órfãos; ela revela Jesus que, por sua vez, revela o Pai; ela forma Jesus em nós; alguns a chamam de alma da Igreja... Segundo Congar, são

\footnotetext{
${ }^{68}$ Cf. BERNARDO, Sermo 88 de diversis,1 (PL 183, 706); De Pentecoste sermo 11 (323). Apud ibidem.

${ }^{69}$ Cf. ibidem. P. 187.

${ }^{70}$ Cf. ibidem. P. 123 , inclusive a nota $\mathrm{n}^{\mathrm{o}} 5$.

${ }^{71}$ Cf. SIMEÃO. Hymnes, ob. cit. XIX, 53-55 (174, 99) ; XLIV, 266-271 (196, 89ss) ; L, 153 ss (p. 169); LI, 95ss (p. 193); etc. Apud ibidem. P. 123, incluindo nota $\mathrm{n}^{\circ} 7$.

${ }^{72}$ Cf. ibidem. P. $172 \mathrm{~s}$.
} 
títulos e funções atribuídos ao Espírito! O próprio papa Leão XIII, em sua encíclica, (que tomou, em parte, do texto de São Bernardino de Siena), é um exemplo disto, quando afirma que:

Toda graça que é comunicada neste mundo chega por um tríplice movimento (...). Deus em Cristo, Cristo na Virgem, a Virgem em nós ${ }^{73}$.

Para melhor visualizarmos a continuidade entre a ação do Espírito em Jesus e a ação do Espírito no AT, recordaremos algumas características básicas desta última. Na revelação veterotestamentária, o Espírito de Deus não nos foi revelado como uma Pessoa, mas algo que se movia como uma potência nas pessoas que Deus chamava para realizar seus desígnios, em ocasiões particulares. Já nos profetas do Exílio que anunciavam uma restauração religiosa, uma interiorização da Lei era prometida como fruto do dom de um espírito novo (cf. Is 32,15; Ez 29,29; Joel 2,28-29) ${ }^{74}$. Congar destaca que o monoteísmo judaico associava a Deus realidades que eram Deus, mas que, em Deus, representavam modos de ação, modos de presença de estar com os seres humanos ${ }^{75}$. Nosso teólogo descobre um fenômeno chamativo na literatura apócrifa e rabínica intertestamentária: a autonomia progressiva da noção de Espírito como pessoa (fala, caminha, exorta, aflige-se, chora, alegrase, consola,...); às vezes, aparece o Espírito falando a Deus. Assim, Congar descobre a importância da noção de Espírito para o judaísmo: segundo ele, é como uma hipóstasis, como um ser pessoal, às vezes semelhante a um anjo. Ruah, no hebraico, ou pneuma, no grego, significa sopro, alento, ar, vento, alma - tanto no AT quanto no NT. A palavra espírito não consegue traduzir o relevo que a palavra sopro traz: há 378 empregos de ruah no Antigo Testamento, significando: vento ou sopro do ar (cf. Jo 3,8; At 2,1-4.6), força viva no humano, princípio de vida (alento), sede do conhecimento e dos sentimentos (cf. Ex 15,8-10; S1 33,6; Gn 7,22; S1 104,29-30; todo livro de Jó) e força de vida de Deus pela qual é obra e faz agir, tanto no plano físico como espiritual.

O AT trata em escassa medida o valor de santificação: ao menos no sentido de um princípio interior de vida perfeita (isto será o fruto da observação da Torah): o Espírito (= sopro) é, em primeiro lugar, o que faz atuar de maneira que se realize o plano de Deus na história. Segundo os testemu-

\footnotetext{
${ }^{73}$ LEÃO XIII. Encíclica Iucunda semper. 1894 (ASS 27 [1894-95] 179. Textos completos e sua crítica em MÜHLEN, H. L'Esprit dans l'Église, trad. Fr., Paris, 1969, t. II, p. 149ss. Apud ibidem.

${ }^{74}$ Cf. idem. Cette Église que j'aime, ob. cit. P. 34-35.

${ }^{75}$ Cf. idem. El Espiritu Santo, ob. cit. P. 29-31;38s.
} 
nhos mais antigos, atribui-se ao Sopro-espírito efeitos externos; já o tempo dos profetas escritores aporta dados que se referem mais ao interior da pessoa: experiência de visão e sabedoria - sente-se manipulada por Javé, inclusive pronuncia (às vezes até contra sua vontade pessoal) um oráculo de Deus (cf. Nm 24,2ss); a pessoa vê o secreto, ouve as palavras de Deus, cai em êxtase, os olhos se abrem; ou é arrebatada de entusiasmo profético (cf. $1 \mathrm{Sm}$ 9,9;10,5-6;19,20-24) - o Espírito a invade, ela se transforma em outra pessoa. Nos referimos aqui à pessoa humana, a seu psiquismo: não existe empresa de Deus sobre a pessoa humana que não ponha em jogo ela mesma. Contudo, em outros estratos tão ou mais antigos, o Espírito vindo de Deus dá um discernimento e sabedoria, conformes ao normal, mas assegurando a realização do plano de Deus para seu povo (cf. Gn 41,38; Nm 11,16ss.25.29;27,18). Os juizes são chefes ou guerreiros carismáticos, suscitados por Deus nas circunstâncias críticas em que se encontrava Israel, durante os 150 anos que separam a conquista de Josué e a instituição da realeza (cf. Jz 3,10; 6,34; 11,29; 13,25; 14,6.19; etc). A partir deste momento, cessa o tipo de empresa momentânea e insólita do sopro (Espírito), até a vinda de Jesus, como testemunha a genealogia de Mateus e Lucas (cf. Lc 3,31).

A Igreja das origens já afirmava que o Espírito que concebeu Jesus e o anima é o mesmo que atuava no AT; igualmente os targúmenos judeus atribuem freqüentemente a Ele o título profecia. O AT anunciava a doação do Espírito nas duas linhas (missão e profecia, e da vida nova) - de um lado, Joel 3, e, de outro, Ezequiel 36,26ss e Jeremias 31,31-34. Também Isaías trata acerca do Espírito, como em 11,2-3, quando aborda sobre seus dons (o profeta não fala de maneira vaga, mas muito concreta: espírito de sabedoria, espirito de conselho, etc ${ }^{76}$ ). Congar também destaca a relação entre Espírito e Sofia, no AT: uma literatura que se desenvolveu nos quatro séculos que precederam a era cristã, que contém uma notável reflexão sobre a sabedoria, ao ponto de dar a impressão de que ela e o Espírito se identificam (ao menos se consideramos suas respectivas ações). O livro afirma que a sabedoria procede de Deus: é sua ação em benefício das criaturas para conduzi-las retamente a querer e fazer o bem. O Espírito da sabedoria consiste em guiar-nos em conformidade com a vontade de Deus: por isso, fixou residência em Israel, formou amigos e profetas; é o livro da aliança, a lei que Moisés prescreveu (cf. Eclo 24,23).

Congar percebe semelhanças entre a sabedoria e o Espírito no AT: a sabedoria possui um espírito (Sb 7,22b) ou é um espírito (Sb 1,6); atua sob a forma de espírito ( $\mathrm{Sb} 7,7 \mathrm{~b}$ ); dispõe do poder e vê como se lhe atribuem as

${ }^{76}$ Cf. TOMÁS DE AQUINO. Summa Theologica, I-II, q. 68, a. 1. Apud ibidem. P. 149. 
diferentes funções do Espírito no AT (exerce um papel cósmico universal, suscita os profetas, guia a humanidade, é a grande mestra interior das almas). Alguns Padres da Igreja consideravam-na como uma prefiguração não do Verbo, mas do Espírito ${ }^{77}$. Recorda-nos Congar que a sabedoria é experienciada também como espirito amigo das pessoas (cf. Sb 1,6; Jó 32,8), que ama os humanos e não deixa impunes os lábios blasfemos - porque o Espírito preencheu o mundo e o que tudo abarca, possui conhecimento de tudo quanto se fala (cf. Sb 1,6.7); na sabedoria, há um espírito inteligente, santo, único, múltiplo, sutil, ágil, penetrante, puro, claro, impassível, amante do bem, agudo, incoercivel, benfeitor, amigo dos homens, firme, seguro, que tudo pode, que está atento a tudo, que penetra todos os espiritos (os inteligentes, os puros, os mais sutis $)^{78}$. A sabedoria é mais ágil que todo movimento - tudo atravessa e penetra, porque é um sopro do poder de Deus, emanação pura da glória do todo-poderoso. Sendo una, tudo pode e, permanecendo a mesma, tudo renova; entra nas pessoas e faz delas amigas de Deus e dos profetas; estende-se de um extremo a outro, tudo governa convenientemente (cf. Sb 7,22-8,1). Porém, nosso teólogo também evidencia uma profunda diferença: ela carece do caráter de uma força ou energia interior de transformação, como acontece com a ação do Espírito.

Congar reflete que a economia de Deus, da qual as Escrituras dão testemunho, progride no sentido de uma interioridade mais profunda - a escatologia será a interiorização absoluta: Deus tudo em todos. Tal progresso é claro no AT: desembocará no NT, unido a uma revelação e a uma experiência mais perfeitas do Espírito ${ }^{79}$. Pode constatar-se um compromisso progressivo, ao mesmo tempo, que uma revelação mais completa de Deus em Jesus Cristo, em quem o Espírito atua, plenamente.

Nosso teólogo assinala com ênfase o elo entre pneumatologia e cristologia: o Pneuma está completamente relacionado a Cristo ${ }^{80}$. Do ponto de vista do conteúdo, não se dá nem autonomia e nem disparidade da obra do Espírito a respeito da de Cristo. Atribui-se, por exemplo, grande número de efeitos, indistintamente, tanto a Um quanto ao Outro (comparar, por exemplo, os seguintes textos apresentados por Congar, que retratam a complementaridade entre as missões do Cristo e do Espírito - os primeiros textos citados referidos a Cristo e, os segundos, ao Espírito: 2 Cor 5,21/ Rm 14,17;

\footnotetext{
${ }^{77}$ Cf. LARCHER, C. Études sur le Livre de la Sagesse. Et. Bibliques. Paris. 1969. P. 411; LEBRETON, J. Les origines du dogme de la Trinité. T. II. Paris. 1928². P. 513; 567; 569-570. Apud ibidem. P. 37-38.

${ }^{78}$ Cf. ibidem. P. 221.

${ }^{79}$ Cf. ibidem. P. 40.

${ }^{80}$ Cf. ibidem. P. 66-67.
} 
Gal 2,17/1Cor 6,11; Rm 8,1-10/ Rm 8,9; Flp 3,1/ Rm 14,17; Rm 8,39/ Col 1,8; Fl 4,7/ Rm 14,17; 1Cor 1,2.30/ Rm 15,16; 2Ts 2,13; 2Cor 2,17/1Cor 12,3; Col 2,10/ Ef 5,18; Rm 12,5 e Gal 3,27/1Cor 12,13; Ef 2,21/ Ef 2,22; etc). Parece-lhe que Paulo atribui a ambos as operações e os frutos da vida cristã; contudo, a maioria dos exegetas reconhece que não existe identificação ou confusão: Paulo apenas define com a palavra pneuma o modo de existência do Kyrios: pneuma kyriou define seu modo de existência. Filho e Espírito estão tão intimamente unidos, que parecem Se fundir, sem, no entanto, Se perder. Do ponto de vista funcional, o Senhor e seu Espírito fazem a mesma obra, mas na dualidade de suas respectivas funções. Nota-se uma conseqüência sacramental: os sacramentos - e a Igreja como grande sacramento - são o lugar em que o Cristo-aliança e salvador, está presente em vista do futuro do mundo, pelo Espírito ${ }^{81}$.

Para Paulo, o Espírito é mais que uma simples força: é uma pessoa ${ }^{82}$. Este, como sujeito: esquadrinha a profundidade de Deus (cf. 1Cor 2,10s), vem de Deus (cf. 1 Cor 2,12), é enviado a nossos corações como dom - como alguém que dá, pois Deus se entrega a nós no Pneuma ( $\mathrm{cf}$. Gal 4,6; Rm 5,5; 1 Tes 4,8), entra ativamente na história da salvação ou em sua realização, faz-nos conhecer a vontade salvífica de Deus (cf. 1Cor 2,10-14), testemunha a nosso espírito que somos filhos de Deus (cf. Rm 8,16), grita em nós Abba (cf. Gal 4,6), intervém a nosso favor junto de Deus (cf. Rm 8,16), distribui os dons como quer (cf. 1 Cor 12,11), habita em nós (cf. 1 Cor 3,16; 6,19)... - para Congar, quem atua dessa maneira, é uma pessoa autônoma e livre. O Pneuma apresenta-se em igualdade com Deus (ho Theos - o Pai) e, sobretudo, com Cristo (cf. 1Cor 12,4-6; 2Cor 13,13): não é uma simples comunidade de ação, mas uma igualdade de três Pessoas no ser.

Congar organiza assim o pensamento de São Paulo acerca dos carismas: são distribuídos pelo Espírito segundo Sua vontade, são diversos e diferentes, com vistas para o bem de todos. O carisma do amor está acima de todos os demais dons do Espírito (ou pneumatika - cf. 1 Cor 12,$1 ; 14,1$ ) ${ }^{83}$. O-a batizado-a recebem carismas para a edificação da Igreja - temos, assim, um belíssimo entrelace entre pneumatologia, antropologia e eclesiologia. Nosso autor, porém, descobriu uma deterioração da maneira paulina de pensar os carismas, apesar da Igreja atestar a teologia correta; nota, por exemplo, que a tradição escolástica viu, nos carismas, as graças gratis datae, e,

\footnotetext{
${ }^{81}$ Cf. idem. Cette Église que j'aime, op. cit. P. 51-52.

${ }^{82}$ Cf. WENDLAND, H.-D. ; WARNACH, V. Das Wirken des Hl. Geist in den Gläubigen nach Paulus. In: Pro veritate. Ein theologischer Dialog (Festgabe L. Jaeger u. W. Stählin, dir. por E. Schlinck e H. Voek). Münster e Kassel. 1963. P. 185-186. Apud ibidem. P. 69-70

${ }^{83}$ Cf. ibidem. P. 63-64.
} 
nos dons extraordinários, o sinônimo de fazer milagres ou curas. Congar notou que os carismas no sentido paulino reapareceram na teologia católica contemporânea, como com Pio XII, em sua Encíclica Mystici Corporis ${ }^{84} \mathrm{e}$ no Vat II.

Em Atos dos Apóstolos, o sujeito das ações da Igreja é o Espírito. Na percepção de Congar, não podemos atribuir a Lucas uma profissão dogmática acerca do Espírito Santo, mas destaca que Lucas sobre-passa, por sua vez, a compreensão veterotestamentária, onde é Deus quem dá seu Sopro: em diversos momentos, Lucas mostra-nos que é o Espírito mesmo quem atua. Pela ação do Espírito, os gentios convertem-se em povo de Deus: os ethne transformam-se em laos (cf. At 15,14): as nações (realidades terrestres) converteram-se em povo (realidade que pertence à ordem da economia da salvação). O Espírito Santo que irrompe em Pentecostes, é, essencialmente, o princípio dinâmico do testemunho, que assegura a expansão da Igreja: o sinal das línguas profetiza a catolicidade do testemunho de Jesus a todos os povos. Congar destaca que é mais do que uma universalização ou um ato de extensão: a peculiaridade do Espírito consiste em estar em todos, permanecendo o mesmo e único, sem tirar a originalidade e a cultura das pessoas e dos povos - isto é expressar as maravilhas de Deus em sua língua. Lucas apresenta uma espécie de pentecostes sucessivos: em Jerusalém (cf. 2; 4,2531), em Samaria (cf. 8,14-17), o acontecimento com Cornélio e o de Cesaréia (cf. 10,44-48; 11,15-17) e o episódio de Éfeso (cf. 19,1-6) - são sinais da intervenção do Espírito (cf. também 2,4-11.17; 10,46; 11,27; 19,6; 20,23; 21,4.11). Os liturgistas anotam que Pentecostes faz parte do ciclo cristológico, formando com a Páscoa uma só festa ${ }^{85}$. A obra do Cristo, desde então, não será mais feita somente para nós só na Pessoa d'Ele, mas estendida a todo seu corpo, até à plenitude que levará à páscoa da parusia. Entre a páscoa de Jesus e a parusia está a Igreja. Nos Atos, Lucas apresenta-nos a continuidade entre Cristo e a Igreja sob o signo do Espírito Santo - é como que o elo, a passagem entre ambos.

Congar adverte-nos de que, se alguém quer pensar a questão da trindade das pessoas na unidade de substância, no plano e nas categorias do dogma trinitário, terá que recorrer à noção bíblica joanina da consubstancialidade e da circumincessão (as Pessoas divinas estão uma na outra), e, à teologia da elevação da humanidade de Jesus, por sua glorificação, à qualidade de Senhor e de Filho de Deus com poder. Na comunidade joanina, o Espírito suscita uma comunhão, em virtude da qual (pela fé e pelo amor) estão em Deus

\footnotetext{
${ }^{84}$ Cf. Números 17 e 47. AAS 35 (1943), 200 e 215. Apud ibidem. P. 65.

${ }^{85}$ Cf. Questions liturgiques et paroisses. 1948, I. P. 60. 1949, II, p. 40; 3, p. 69. 1951, 5, p. 124; etc. PIERRET. L'Ami du Clergé. 1935. P. 278s; 281. Apud ibidem. P. 116.
} 
e Deus está neles (cf. 1Jo 4,13; 3,24; Jo 14). Em Jo 3,34, Cristo dá o Espírito sem medida (cf. 7,38-39; 19,34; 14,26; 15,26; 16,14; 20,22), em consonância com o testemunho do Batista (cf. 1,32) - porque Cristo recebeu o Espírito sem medida, pronuncia as palavras de Deus e realiza a sua obra. Congar relata-nos que em João 4,13-14, no encontro com a samaritana, trata-se do Espírito que Jesus dará: o Espírito é aquele que encoraja e anima o fiel para a vida eterna, do mesmo modo como a água viva, que vem de e volta para Deus. Em 6,35, Cristo dá também a vida eterna, pela fé nele (cf. 3,36; 5,21.40; 6,33.35; 7,33-39; 10,10; 20,31) - como em Paulo, Cristo e o Espírito operam a mesma obra de salvação.

Vários autores admitem que os rios de água viva manam do Messias: para o israelita, a recordação da água da rocha no deserto, ligava-se ao anúncio escatológico de um novo milagre ou de uma fecundidade que brota do Templo sob a forma de água viva de uma fonte (cf. Sl 113-118). Jesus aplica a promessa feita ao povo (de beber desta água) a si mesmo: Jesus é o templo (cf. 2,21), do qual Ezequiel viu sair as águas vivificantes (cf. 47,1-12; cf. Ap $21,22 ; 22,1)$. Congar vê aqui uma segunda imagem do Espírito: antes, sopro, e, agora, água. No quarto Evangelho, Jesus auto-apresenta-se como a realização perfeita de todas essas imagens (rocha, templo, torah).

Segundo João, o Espírito procede do Pai - ekporeuetai - mas para tou patros, de junto ao Pai, não ek (cf. 15,26); diz-se, de outra parte, receberá do meu - ek tou emou lepsetai, porque tudo o que tem o Pai é meu (16,14-15). Portanto: o Pai é a origem absoluta e primeira, tanto do Verbo quanto do Espírito Santo. O evangelho de João refere-se ao Paráclito, que é o Espírito. Segundo Jesus (cf. 14,17; 15,26; 16,13), é um outro Paráclito, juntamente com Jesus (cf. 14,16). O termo grego Parakletos - ou, como o disseram São Jerônimo e os judeus: "prqlty", porque não existe outro termo que traduza adequadamente todos os valores de tal palavra grega -, significa defensor, consolador, auxiliador, advogado, procurador, conselheiro, mediador, o que exorta,... Como sujeito, o Paráclito: é Espírito da verdade, é Santo; mora com os discípulos (cf. 14,17), estará neles (cf. 14,17), vem (cf. 16,7s.13), recebe do que é de Jesus (cf. 16,14s), procede do Pai (cf. 15,26), escuta (cf, 16,13 ), ensina (cf. 14,26), recorda (cf, 14,26), comunica (cf. 16,13ss), fala (cf. 16,13), glorifica (a Jesus - cf. 16,14), guia à verdade plena (cf. 16,13), dá testemunho (cf. 15,26),... O Paráclito, para João, não é apenas sujeito, mas, também, objeto: é dado (cf. 14,16), é enviado (cf. 14,26; 15,26; 16,7), não é visto nem conhecido (cf. 14,17), não é recebido (cf. 14,17).

Assim, podemos afirmar que o Espírito Paráclito segue a marcha de Jesus (revelar o Pai) e continua a obra de Jesus. A revelação do Pai em Jesus deverá ser vivida pelos discípulos - e isto é trabalho do Espírito. O Espírito 
não inventa nada, não introduz outra economia, mas vivifica o Corpo (= Igreja) e recorda as palavras de Jesus (cf. 6,63). O Espírito-Paráclito revela Jesus aos discípulos, e Jesus, por sua vez, revela o Pai - temos, aqui, em João, a economia trinitária, que, segundo Congar, é notável: o Espírito aponta completamente ao testemunho dado em favor de Jesus, e, este, está totalmente voltado para o Pai. Jo 3,31-36, para Congar, é a passagem que melhor resume esse mistério: Jesus vem do céu (= eternidade) (cf. Jo 1,30.34), João o batiza e vê descer o Espírito como pomba sobre Ele, e o Homem-Jesus, Palavra feita carne, vive, na sua humanidade, a referência total ao Pai. Em virtude desta referência, é todo do Pai e todo para o Pai, em direção ao Pai (pros ton Theon - cf. 1,1; 1Jo 1,2). Quando Jesus tem que abandonar a terra, envia seu Espírito como água viva no interior dos crentes - como Paráclito. Para João, o Paráclito é o Espírito, não em sua relação ad intra trinitária, mas ad extra, e, nesta, especialmente, no interior dos crentes, atuando conjuntamente com a palavra, a água do batismo, a eucaristia, o testemunho, o ministério de reconciliação.

O envio do Espírito Santo está forte e expressamente ligado por São João à vinda e à paixão do $\mathrm{Cristo}^{86}$, fato que está expresso em lugares diferentes, ora sob uma forma simbólica, ora claramente, como no célebre texto de Jo 7,39, cuja interpretação, sem dúvida unânime, fica independente da maneira de pontuação e do entendimento dos dois versículos precedentes: $O$ Espírito não estava ainda porque Jesus ainda não fôra glorificado. Também em Jo 19,30: E, inclinando a cabeça, entregou o espirito. Nos dois casos, o envio do Espírito Santo está ligado à Paixão, ao corpo imolado do Verbo encarnado: o Cordeiro que o Apocalipse nos mostra assentado com Deus sobre um mesmo trono, de onde jorra o fluxo de água viva (cf. Ap 22,1s). Ainda há um outro texto de São João que manifesta a ligação do Espírito ao Cristo: Jesus ressuscitado vem ao meio dos seus, sopra sobre eles e diz: Recebei o Espírito Santo - o verbo empregado significa o modo pelo qual se opera uma criação, cura ou destruição: ou seja, a nova criação de Pentecostes foi ligada diretamente ao Cristo por São João (para alguns autores, João, para marcar melhor esta ligação, situou Pentecostes no dia mesmo da Páscoa: não historicamente, mas, simbólica e dogmaticamente).

Portanto, percebemos, em toda essa reflexão congariana, que o Espírito Santo faz a própria obra de Cristo! Entretanto, existe o seu próprio papel $^{87}$. A revelação bíblica nos mostra que, apesar de intrinsecamente unidas, cada uma - cristologia e pneumatologia - possuem sua própria identidade e autonomia, aqui reveladas no âmbito da ação. Podemos também captar, das

${ }^{86}$ Cf. idem. Introdução ao Mistério da Igreja. Ob. cit P. 114-115.

${ }^{87}$ Cf. ibidem. P. 109-110. 
Escrituras e seguindo Congar, algumas dessemelhanças entre a obra de Cristo e a obra do Espírito: Cristo cria uma realidade objetiva de graça, verdade, salvação e revelação, enquanto o Espírito a aplica e interioriza. Cristo realizou, uma vez para sempre, em Si mesmo, a união da humanidade com Deus e, o Espírito, estende- $a$ e apropria- $a$ a um grande número de pessoas. Cristo propôs a Palavra de Deus e, o Espírito, lembra-a no íntimo das pessoas e inclina o coração a compreendê-la. Cristo construiu a casa (= morada de Deus no ser humano), enquanto o Espírito mora nela (cf. Ef 2,22). Cristo dá a qualidade de filho-a a seus seguidores e seguidoras e, o Espírito, torna nosso coração consciente da qualidade de filho-a e nos faz cumprir as obrigações e os atos dessa filiação (cf. Gl 4,4-6; Rm 8,15). Cristo dá, tanto à alma individual como à Igreja, a prerrogativa de existir na nova criação, enquanto o Espírito faz essa nova criação produzir frutos, dá a este corpo sua alma, e faz os dons salutares chegarem até seu cumprimento;...

O Espírito relembra tudo o que Cristo disse (cf. Jo 14,26). Ele não deixa de guiar em toda verdade, de anunciar as coisas que estão para chegar (cf. Jo 16,13), mas não faz coisas novas em relação à obra do Cristo. Ele conduz tudo a seu cumprimento - e, o cumprimento de toda a criação, é ser em Cristo. Tomando, como de trás, aquilo que é do Cristo, Ele anuncia-o antes (cf. Jo 16,16) - isto é: se toda a criação é feita por Cristo e com Cristo, o Espírito trabalha essa mesma criação para sua maturidade e plenitude em Cristo. Mesmo antes da plenitude em Jesus, o Espírito, sabendo de antemão o destino da criação, a trabalha para a plena maturidade da mesma - um movimento pelo qual Ele tende levar ao fim o gérmen que o Verbo, no Cristo, lançou nela. Entre as duas exaltações do Cristo - a páscoa que Ele faz para nós e a que faremos com Ele - o Espírito Santo age, para fazer crescer e frutificar o Ae o $\Omega$.

\section{Conseqüências teológico-eclesiológicas}

\section{1 - Uma Igreja comunional}

A base do pensamento de Congar, como vimos, é a cristologia pneumatológica e a pneumatologia cristológica, articuladas. Ambas são a base da reflexão acerca da Igreja-Comunhão, pois ambas refletem ambas as missões dos enviados do Pai: a do Filho e a do Espírito. O Filho e o Espírito refletem a natureza da Trindade, que é o Amor Comunional, a Comunhão.

Nesta linha de reflexão - a Igreja Comunhão -, Congar destaca que o batismo produz uma igualdade ontológica de todos os membros, anteriormente a qualquer distinção dada pelos carismas doados pelo Espírito e pelo 
estado de vida de cada membro. Cabe, aqui, lembrar a virada copernicana que o Vaticano II imprimiu à eclesiologia, ao colocar, na Constituição Dogmática Lúmen Gentium (LG), o segundo capítulo sobre o Povo de Deus antes do terceiro, que trata da constituição hierárquica da Igreja. Há, portanto, a prioridade da communio fidelium em sua totalidade - por isso, Congar recorda a existência de uma dupla infalibilidade: in credendo e in docendo (enquanto se crê e enquanto se ensina) e Congar adverte que seria falso interpretá-las sem mais - como infalibilidade passiva e infalibilidade ativa, por exemplo - pois todos, povo e hierarquia, participam, cada qual a seu modo, de ambos os aspectos, o que é confirmado pelo próprio Concílio ${ }^{88}$.

Somos batizados em um só Espírito, para sermos um só corpo (cf. 1 Cor 12,13). No batismo de Jesus, pela efusão do Espírito Santo, há a consagração e a missão. Portanto, o batismo das seguidoras e dos seguidores de Jesus passa a ter, igualmente, ambas características. $\mathrm{O}$ batismo é anterior a qualquer vocação - portanto, se o padre é ordenado e, o bispo, sagrado, todo batizado é com-sagrado, ou seja: sagrado com os outros, feito sagrado um com os outros. O batismo produz uma igualdade ontológica de todos os membros, anteriormente a qualquer distinção dada pelos carismas doados pelo Espírito e pelo estado de vida de cada membro. É esta comunhão que é alimentada e celebrada em ação de graças na Eucaristia.

A Igreja Povo de Deus, segundo a Constituição Dogmática do Concílio Vaticano II Lúmen gentium, é uma diversidade na unidade:

\begin{abstract}
Pois como em um só corpo temos muitos membros, mas todos os membros não têm a mesma função, assim nós, embora sejamos muitos, somos um só corpo em Cristo, e cada um de nós somos membros uns dos outros' (Rom 12,4-5), em 'um só Senhor, uma só fé, um só batismo' (Ef 4,5).
\end{abstract}

A Constituição reafirma que são comuns a todos os fiéis: a dignidade, a graça de filhos, a vocação à perfeição. Há uma salvação, uma esperança e uma caridade:

Não há, pois, em Cristo e na Igreja, nenhuma desigualdade em vista de raça ou nação, condição social ou sexo, porquanto 'não há judeu ou grego, não há servo ou livre, não há varão ou mulher, porque todos vós sois um em Cristo Jesus' (Gl 3,28 grego; cf. Col 3,11)”.

\footnotetext{
${ }^{88}$ Cf. LG n ${ }^{\circ}$ 12. CONGAR, Yves. "Infalibilidad e indefectibilidad. El concepto de "infalibilidad”, em K. RAHNER (ed.), La infalibilidad de la Iglesia. Respuesta a Hans Küng. Madri. 1978. P. 161.
} 
Há entre todos os membros verdadeira igualdade quanto à dignidade e ação comum na edificação do Corpo de Cristo. LG afirma que a distinção entre os membros traz em si certa união; a diversidade das graças, ministérios e trabalhos unifica os filhos de Deus, porque em tudo isso opera um e o mesmo Espirito (1 Cor 12,11). Igualmente Congar tem consciência disto: afirma que, com efeito, Deus reúne e constrói sempre atualmente sua Igreja: é Deus quem chama (cf. Rm 1,6; cf. 1 Cor 1,2; 2 Cor 1,1: povo de Deus); é Deus quem faz crer (cf. 1 Cor 3,6). O corpo inteiro recebe do Cristo a harmonia e a coesão por todas as espécies de ligações, operando assim seu desenvolvimento (cf. Ef 4,16). É Deus quem estabelece a uns serem apóstolos, outros profetas ou doutores (cf. 1 Cor 12,28$)^{89} \ldots$ Certamente, ele utiliza para isto o serviço e o ministério das pessoas; contudo, estas completam um puro serviço à ação envolvente de Deus (Paulo e Apolo são apenas servidores pelo meio do qual vós crestes - 1 Cor 3,5b).

Congar disserta que o Espírito, transcendente e único, pode penetrar tudo sem violentar nada; é único e onipresente, transcendente e interior a todos, sutil e soberano, respeitoso das liberdades e poderoso para inspiralas ${ }^{90}$. Ele, ainda, pode promover o plano de Deus, que se expressa nas palavras: comunhão, muitos em um, unipluralidade. No final, Deus será tudo em todos (1 Cor 15,28) - haverá uma vida única animando a uma multidão, mas sem profanar a interioridade de nada (como, no Sinai, Deus fazia arder a sarça, sem consumi-la). Continua nosso teólogo, afirmando que, no Concílio Vaticano II, foram manifestadas tensões sobre diferentes pontos ${ }^{91} .$. Entretanto, ele afirma que havia entre eles uma comunhão fundamentalmente perfeita, que explodia, talvez, mais em seus desacordos que em seus acordos. Segundo Congar, o desacordo mostra, por seus próprios limites, a potência e a eficácia da comunhão sobre o qual são enxertados os ramos divergentes!

A igualdade ontológica a partir do batismo, resgatada pela eclesiologia de comunhão do Vat II, foi reconhecida pelo atual Código de Direito Canônico, no cânon 208 (fundamentado, como se pode perceber claramente, em LG 32):

Entre todos os fiéis, pela sua regeneração em Cristo, vigora, no que se refere à dignidade e atividade, uma verdadeira igualdade fundamental, pela qual todos, segundo a condição e os múnus

\footnotetext{
${ }^{89}$ Cf. idem. Ministères et Communion Ecclésiale. Les Éditions du Cerf. Paris. 1971. P. 36.

${ }^{90}$ Cf. idem. El Espiritu Santo. Ob. cit. P. 221.

${ }^{91}$ Cf. ibidem. P. 95.
} 
próprios de cada um, cooperam na construção do Corpo de Cristo $^{92}$.

\section{2 - Uma Igreja toda ministerial}

Se, pelo batismo, somos todos e todas, ontologicamente, iguais - o que fundamenta teologicamente a Igreja Comunhão -, também, pelo batismo, somos, ministerialmente diferentes. Ousamos afirmar que, na vivência da diferença na realidade eclesial, é que reside nosso desafio pastoral. Segundo nosso teólogo, o elemento da diversidade é importante para a Igreja: ela não deve, principalmente como fez no passado, confundir unidade com uniformidade $^{93}$ - igualdade não quer dizer ser idêntico, e, segundo nosso teólogo, o ecumenismo é uma das realidades mais ricas que ajudam a Igreja a não fazer tal confusão, porque nos ajuda a pensar não imperialmente. Nossa solicitude deveria sempre ver os outros diferentes como pessoas, sujeitos originais de projetos e de iniciativa - e pessoas diferentes. Segundo Medoro Souza Neto, a comunhão exige respeito pela iniciativa do outro, uma certa autonomia das partes - ou seja: reconhecimento da alteridade $e^{94}$. A questão de fundo, aqui, é que o outro é diferente; assim, trabalhar as relações de comunhão é, fundamentalmente, trabalhar o dado da diferença, e, não tanto, o da igualdade.

A eclesiologia de comunhão - como afirma Bruno Chenu - deverá medir as diferenças sociais, culturais, religiosas e cristãs, que tantas vezes separam, conflituam ou mesmo opõem seres humanos entre $\mathrm{si}^{95}$. Em seu ministério, Jesus deu atenção a todos aqueles e aquelas que não eram como os outros, ele mesmo portador de uma diferença inigualável (cf. Jo 5,18) e, não obstante, pretende reunir todos os filhos e filhas de Deus nesta diferença (cf. Jo 17,21). É uma reunião que não mata a diversidade (cf. Jo 14,2). Não devemos nos esquecer que é a unicidade de Deus que é a fonte de toda diversidade - o ser humano semelhante a Deus é diferente de Deus! O ser humano existe, portanto, à semelhança da diferença de Deus - é um ser à parte, mas capaz de significar o Único. A vocação do ser humano é, exatamente, a proclamação da glória do Deus único no seio de uma comunidade fraterna. En-

\footnotetext{
92 Apud SOUZA NETO, Medoro Oliveira. Maturidade eclesial,comunhão e ministérios. Um estudo crítico-teológico sobre a participação dos fiéis nas decisões da Igreja,a partir das CEBs. Tese Doutoral, pela Pontifícia Universidade Católica do Rio de Janeiro. 1994. P. 48.

${ }^{93} \mathrm{Cf}$. CONGAR, Yves. Cette Église que j'aime. Ob. cit. P. 81.

${ }^{94}$ Cf. SOUZA NETO, Medoro Oliveira. Ob. cit. P. 39.

${ }^{95}$ Cf. CHENU, Bruno. " 'Nossas diferenças têm o sentido de uma comunhão?'. À memória de Christian de Chergé, prior de Tibhirine (Argélia)". In: Concilium/280 - 1999/2. Editora Vozes. P. 150[334]-162[346].
} 
tretanto, no meio eclesial, geralmente, entende-se diferença como divisão, ruptura - aliás, uma grande parte da história da Igreja consistiu em reconduzir o outro a si. A novidade dos tempos atuais é o reconhecimento do outro como outro e a valorização de sua particularidade: o desafio é converter o temor da diferença nefasta em alegria da diferença enriquecedora.

Os ministérios devem ser compreendidos em sua viva relação com a comunidade total $^{96}$. Os ministérios, como sabemos, estão referidos e possuem sua base teológica na reflexão sobre o batismo. $\mathrm{O}$ batismo dos seguidores e das seguidoras de Jesus assume as características do batismo de Jesus: o crente se torna filho ou filha de Deus, e passa a ter a mesma relação que Jesus teve com o Pai no momento de seu batismo no Jordão (salvo as diferenças de natureza). É um fato para Congar que todos os fiéis possuem relação com o batismo de Jesus ${ }^{97}$, onde Ele comprometeu seu destino de Messias, ao mesmo tempo, sofredor e destinado à glória - ou seja: há, indiscutivelmente, uma relação profunda entre batismo e eclesiologia.

A questão da pluralidade, da diferença interessa - e muito - à teologia dos ministérios. Segundo Congar, o plural é, aqui, essencial, pois significa que a Igreja de Deus não se constrói somente pelos atos do ministro oficial do presbiterado, mas por uma multidão de serviços diversos, mais ou menos estáveis ou ocasionais, espontâneos ou reconhecidos, eventualmente consagrados à parte da ordenação sacramental ${ }^{98}$. Nosso teólogo apresenta uma lista de ministérios presentes nas comunidades eclesiais de sua época: mães que catequizavam as crianças da vizinhança, animador de celebração litúrgica, leitor de textos sagrados, visitante de doentes ou de prisioneiros, secretário paroquial, organizador de círculo bíblico, membro de uma equipe de catequese de adultos, secretário-a da Ação Católica ou de algum movimento de ajuda às Missões, iniciador de uma ajuda aos desempregados ou de uma acolhida aos migrantes, animador de lares, de cursos de alfabetização... A lista, pelo menos aqui no Brasil, seria bem mais extensa ${ }^{99}$ !

Congar adverte-nos que os ministérios realçam - se não a construção da Igreja - ao menos de sua diaconia. Os diversos serviços procedem dos dons de natureza ou de graça, daquilo que São Paulo denomina de carismas - assim chamados, segundo Congar, porque são feitos para a unidade comum (1 Cor 12,7.11) $)^{100}$. Congar nos alerta a necessidade de reconhecer o lugar e o valor dos ministérios na eclesiologia - inclusive sugere que a pola-

\footnotetext{
${ }^{96} \mathrm{Cf}$. CONGAR, Yves. Ministères et Communion Ecclésiale. Ob. cit. P. 8.

${ }^{97}$ Cf. idem. El Espíritu Santo.Ob. cit. P. 47.

${ }^{98}$ Cf. idem. Ministères et Communion Ecclésiale. Ob. cit. P. 17.

${ }^{99}$ Cf. SOUZA NETO, Medoro Oliveira. Ob. cit. P. 17-27.

${ }^{100}$ Cf. CONGAR, Yves. Ministères et Communion Ecclésiale. Ob. cit. P. 17.
} 
ridade decisiva para tal empreendimento não é a sacerdócio-laicato que ele usa em sua obra Jalons pour uma théologie du laïcat, mas a dos ministérios ou serviços-comunidade.

$\mathrm{O}$ interessante, aqui, é percebermos que somos chamados, sim, à comunhão, mas a partir de nossas diferenças vocacionais elou ministeriais. $\mathrm{E}$ assim o somos exatamente para sermos Um com Deus e entre nós: este é nosso ponto de partida (= batismo), nosso alimento (= eucaristia) e nosso ponto de chegada (= escatologia). O Espírito faz nascer a vida cristã e anima a Igreja a ser o Corpo de Cristo - há, portanto, uma única vocação primeira na Igreja, a saber: ser o Corpo de Cristo. É uma única vocação, gerada pelo Espírito nos batizados, que, pela ação do próprio Espírito, produz uma enorme gama de diversidades: de dons, de ministérios, de operações, de carismas... É o mistério paradoxal produzido pelo Espírito: da unidade à diversidade - um só batismo, um só Corpo, um só Espírito (cf. 1Cor 12,4-13), que só se efetua plenamente na variedade de dons, carismas, ministérios, operações,... dos diversos chamados ao batismo e pelo batismo.

\section{3 - Uma Igreja serva e despojada}

Outro traço de Congar é sua solidariedade à Igreja dos pobres - inclusive, dedica uma de suas obras ao Cardeal Lercaro, que ele intitula como 'o Advogado dos Pobres, ${ }^{101}$. Nesta linha, defende uma Igreja sem autoritarismo: uma Igreja de serviço. Ele cita, entre os vários exemplos da hierarquia que se destacaram nessa busca o papa João XXIII. Aqui, na América Latina, entre outros, poderemos nos lembrar de D. Oscar Romero e, no Brasil, D. Hélder Câmara... Para Congar, a religião une as pessoas nas realidades situadas além daquilo que as diferencia e as opõe ${ }^{102}$. Mesmo que não sejam realidades somente teóricas: ele cita como exemplo a situação entre ricos e pobres, povos providos e povos miseráveis - uma diferença muito revoltante que, segundo Congar, deve ser diminuída pela partilha que a caridade impõe.

No NT, a verdade da relação com Deus aparece condicionada pela verdade da relação fraternal. Quando São Paulo recebe Onésimo, o escravo fugitivo, ele o reenvia a seu dono Filêmon: Paulo não declara abolida a estrutura econômico-social da escravidão, mas afirma que a fé colocou, entre o dono e o servidor, e entre os dois e Paulo, uma realidade nova, geradora de relações novas; a tal ponto que, se Filêmon a compreende, ele não poderá ter Onésimo como escravo como outrora...

\footnotetext{
${ }^{101}$ Cf. idem. Igreja serva e pobre. Ob. cit. P. 5-7.

${ }^{102}$ Cf. idem. Cette Église que j'aime. Ob. cit.. P. 77-78.
} 
Congar afirma que a Tradição permite que a diversidade se afirme no interior da Igreja - um pouco como nas famílias, onde cada filho tem seus próprios gostos e caráter. Mas ela, a Igreja, é a família, o lar, a casa que habitamos: a unidade da Igreja é plenamente católica ${ }^{103}$. Também neste sentido, a reflexão acerca da Igreja Comunhão questiona a nossa casa, a Igreja: ela nasceu para servir, a exemplo de Seu Mestre. Segundo o próprio Congar, em 1930, data de sua ordenação presbiteral, a Igreja era apresentada como uma sociedade organizada, constituindo-se pelo exercício de poderes, investidos de forma descendente no papa, nos bispos e sacerdotes; e a eclesiologia consistia, quase que exclusivamente, um tratado de direito público ${ }^{104}$. Foi quando criou a palavra hierarquiologia, para definir tal situação eclesiológica.

Ele não acreditava que essa apresentação da Igreja pudesse cativar as pessoas. Em grande parte de sua vida, foi motivado por esta questão: em que medida a Igreja, como tal, pode e deve aplicar a si os conselhos evangélicos que ela costuma reservar aos cristãos em geral, como: perdoar os inimigos, oferecer a face esquerda, preferir os pobres, superar o espírito de ter e de poder $^{105}, \ldots$ ? A índole de todo- $a$ batizado-a é o Amor e, não, o funcionalismo - não devemos agir tecnicamente, de forma mecanicista: quem ama, possui atitude de oblação, liberdade, doação, sem busca de retorno. É a incondicionalidade do amor, nascida da sedução de Deus sobre nós. A vocação à vida é um aspecto fundamental da missão da Igreja; aliás, o elemento antropológico é anterior ao eclesiológico: somos, primeiro, chamados à vida, antes de ser Igreja. Portanto, a atenção a este aspecto primordial é sinal de compromisso com uma diaconia social: um serviço à vida, principalmente onde ela está mais ameaçada.

\section{4 - Uma Igreja afetada pela Eucaristia}

Não diretamente em Congar, mas inspirados nele, queremos encerrar este artigo - a guisa de conclusão - com esta reflexão acerca da Eucaristia. A Eucaristia é a presença encarnada de Jesus Cristo hoje ${ }^{106}$ - ou seja, é Jesus feito carne, corpo, sangue. A comunhão é a carne da Igreja, como nos ajuda a refletir Tillard ${ }^{107}$ : a comunhão não se situa apenas no plano da comunhão hierárquica dos responsáveis da Igreja, mas é muito mais ampla e profunda.

\footnotetext{
${ }^{103}$ Cf. idem. El Espíritu Santo. Ob. cit. P. 18.

${ }^{104}$ Cf. idem. Ministères et Communion Ecclésiale. Ob. cit. P. 10.

${ }^{105}$ Cf. idem. Igreja serva e pobre. Ob. cit. P. 9.

${ }^{106}$ Cf. RUETHER, R. "Refletindo sobre criação e destruição - Reavaliação do corpo no ecofeminismo". In: Concilium 295 - 2002/2. Editora Vozes. P. 44[180]-54[190].

${ }^{107}$ Cf. TILLARD, J. Carne de la Iglesia, carne de Cristo. En las fuentes de la eclesiologia de comunion. Colection Verdad e Imagen. Salamanca/Espanha. Ediciones SIGUEME. P. 9-13.
} 
Para a tradição comum dos primeiros séculos, a existência cristã, em todos seus aspectos e em todos os seus elementos, é, integramente, uma existência de Igreja. Absolutamente nada escapa ao abraço comunitário ao qual o batismo introduz e que a eucaristia sela e significa. A Tradição dos primeiros séculos concebeu e transmitiu o vínculo existente entre a pertença à Igreja e a eucaristia como o acontecimento sacramental, onde a Igreja, existente em um lugar determinado, expressa sua natureza de grupo de diversidade humana, em Jesus Cristo, que a reconcilia com o Pai e reconcilia seus membros entre si, no Espírito.

É esta visão (que é patrística, segundo Tillard), que deseja conservar (nós diríamos resgatar) a eclesiologia de comunhão. $\mathrm{O}$ autor descobre nas parêneses ou exortações - que constituem grande parte dos livros mais importantes sobre a eucaristia - uma insistência muito maior na glorificação de Deus e no comportamento que devemos adotar com os outros do que numa ética centrada no próprio indivíduo. Assim, se se quisesse definir, com uma palavra, a inspiração fundamental do comportamento cristão, Tillard usaria comunhão.

Tal comunhão implica não somente no serviço, mas na vontade de estar com os demais, na confissão comum de Deus e Pai de Jesus Cristo, e no dinamismo do Reino ${ }^{108}$. Não queremos, aqui, repetir toda a fundamentação bíblica para o estar com os outros em Cristo no Espírito, que Congar demonstra tão bem; recordemos apenas algumas citações. Em Paulo, a relação com o outro é essencial para a existência cristã (cf. 2 Cor 5,15) e é em Cristo que se cumpre a relação de Deus Pai com a humanidade (cf. Rm 5,10; 8,3139). Cristo é a tal ponto o outro em cuja comunhão se vive toda a existência cristã, que esta pode ser descrita perfeitamente como a vida de Cristo no crente (cf. Gl 2,19-20; 6,17; 2 Cor 4,10; Fl 1,21; Cl 1,24; 3,3): não há nada na vida do cristão que escape do domínio de Cristo (cf. 2 Cor 5,15; Rm 6,11; Gl 2,19)! O paradoxo está em que, somente deixando-se possuir por Cristo e ser animado por seu Espirito, é que o crente conhece a autêntica liberdade: a de filhos do Pai no Filho, em que consiste a salvação (cf. 1 Cor 1,9).

Trata-se de comunhão, não de absorção (cf. 1 Cor 1,9), como também já refletiu Congar. O em Cristo de Paulo está estreitamente relacionada com no Espírito. Freqüentemente, Paulo refere-se ao Espírito como de Deus, sendo Cristo o Filho de Deus e, a Igreja, o Corpo do Cristo: receber de Deus a salvação é estar agregado a um corpo - o Corpo de Cristo, a Igreja -, animado pelo Espírito de Deus. Esta constatação implica que a reconciliação com Deus é inseparável da entrada na unidade fraternal do Corpo de Cris-

${ }^{108}$ Cf. ibidem. P. 13s. 
to; implica também aos outros, que são os membros vinculados do corpo de Cristo, sendo os mais débeis vinculados aos mais fortes (cf. 1 Cor 12,26). Portanto, não é uma vida em Igreja, mas uma vida de Igreja - como destaca Tillard.

A lei evangélica deste corpo existe em termos de solidariedade fraternal e de comunhão no serviço mútuo (cf. Rm 12,4-21). Paulo se preocupa com as relações fraternais (sobretudo com os mais débeis), vê nelas o material para um culto espiritual, no qual se glorifica a Deus na comunhão fraternal (cf. Rm 15,5-6; Fl 2,1-11) ${ }^{109}$. Na Carta aos Efésios, o autor coloca no coração da fé a abolição da divisão, por obra da cruz; exalta a unidade que resulta de Cristo; a origem do mesmo e único corpo, com seu mesmo e único Espírito, está na destruição, pela cruz, dos muros de separação, de onde advém sua lei essencial, o amor. Os comportamentos dos cristãos devem ter como norma cotidiana os outros, para construir, na unidade, o corpo de Cristo.

O dinamismo do corpo submerge suas raízes no único Espírito (vive em Cristo aquele ou aquela que, em seu comportamento cotidiano, pelo Espirito, se assimila ao Senhor Jesus). Ainda na Carta aos Efésios, Tillard reflete que a Igreja-esposa se apresenta efetivamente como a própria carne de Cristo-esposo (cf. 5,27-32), seu próprio corpo. O autor da Carta vê o corpo inteiro em sua relação, ao mesmo tempo, com sua cabeça (cf. 5,23 ) e com seus membros (cf. 5,29-32). Tillard decorre daí algumas conseqüências importantes: um só corpo em muitos membros diferentes - tanto as pessoas como as Igrejas locais são conduzidas pelo Espírito a um aprofundamento e a uma apropriação tais que tenham em conta seu caráter próprio e convertam tudo isto em uma riqueza eclesial. Assim, dentro da lógica da lei e da encarnação, a comunhão dentro de cada Igreja local e das Igrejas locais entre si (cf. 1 Cor 1,1-3) unifica a variedade da criação e os diversos contextos históricos.

O fiel vive em plenitude esta existência reconciliada em seu destino pessoal: ele não desaparece em meio de uma totalidade, segue sendo o objeto do amor de Deus que recai sobre sua pessoa, sobre suas necessidades, sobre sua própria ressurreição (cf. Gl 2,20) - no silêncio da oração e na intimidade de seu "ser interior" se vê convidado a entabular com Deus as relações pessoais de comunhão (cf. Fl 3,7-16.20-21) ${ }^{110}$. Entretanto, não é somente uma relação pessoal de um crente com Deus: é uma relação pessoal com Deus, mas como membro do Corpo de Cristo, no Espírito. Esta relação pessoal com Deus deve extravasar-se nas relações com os outros membros do Corpo

${ }^{109}$ Cf. ibidem. P. 18s.

${ }^{110}$ Cf. ibidem. P. 23-28. 
eclesial e a sua relação com sua comunidade local deve ser análoga à relação desta comunidade local com outras comunidades eclesiais (cf. At 4,3235; 11,27-30; 2Cor 9,11-15).

Para Paulo, a Igreja não é uma soma de comunidades, mas comunidades em comunhão, como, para João, os discípulos são os ramos que estão na vide, que é Jesus, assim como Jesus está nos ramos (cf. 15,4.5.6.7.9.10) - é o mesmo vínculo: entre Jesus e o Pai e entre Jesus e os discípulos, a saber, o Espírito (cf. 15,26-27; 16,13.14-15) - onde há ágape, ali o Espírito permanece (cf. 14,17-23).

\section{Résumé}

En célébrant la Vème Conférence de l'Église de l'Amérique Latine et Caraïbes, nous sentions le besoin de revenir au Vatican II et, en lui, récupérer des contributions de Ives Congar, en ce que concerne les thèmes de l'Eglise communion et l'exercice du ministère hiérarchique en communion avec tous les fidèles, à la lumière de la communion péricorétique inter trinitaire.

Eva Aparecida Rezende de Moraes

Doutora em Teologia pela PUC-Rio

Professora do Departamento de Teologia da PUC-Rio Professora do Instituto Teológico Franciscano de Petrópolis

\section{Bibliografia}

CONGAR, Y. El Espiritu Santo. Sección de Teología y Filosofia. Barcelona. Editorial Herder. 1991².

- Ministères et Communion Ecclésiale. Les Éditions du Cerf. Paris. 1971.

- Vraie et fausse reforme dans l'Église. Les Éditions du Cerf. Paris. 1968.

- À mes frères. Collection Foi Vivante, 71. Paris. Les Éditions du Cerf. 1968.

- Igreja serva e pobre. Coleção Teológica. Vol. 5. Editorial Logos. Lisboa. 1968.

- Cette Église que j’aime. Les Éditions du Cerf. Paris. 1968.

- Introdução ao Mistério da Igreja. São Paulo. Editora Herder. 1966.

- "Dum visibiliter Deum sognoscimus". In: Les voies du Dieu vivant. Paris. 1962. P. 79-108. 
- Sainte Église. Les Éditions du Cerf. Paris. 1963.

- "Infalibilidad e indefectibilidad. El concepto de "infalibilidad", em K.

RAHNER (ed.), La infalibilidad de la Iglesia. Respuesta a Hans Küng. Madri. 1978.

\section{Demais autores:}

BRITO, E. J. C. O leigo cristão no mundo e na Igreja. Coleção Fé e Realidade, VII. São Paulo. Edições Loyola. 1980.

CHENU, Bruno. “ 'Nossas diferenças têm o sentido de uma comunhão?'. À memória de Christian de Chergé, prior de Tibhirine (Argélia)". In: Concilium/280 - 1999/2. Editora Vozes. P. 150[334]-162[346].

LARCHER, C. Études sur le Livre de la Sagesse. Et. Bibliques. Paris. 1969.

LEBRETON, J. Les origines du dogme de la Trinité. T. II. Paris. $1928^{2}$.

MORAES, E. A. R. Odres novos para um vinho novo: a eclesiologia de comunhão de Ives Marie-Joseph Congar Tese PUC-Rio. 2004.

RAHNER, K. "Theos en el Nuevo Testamento". In: Escritos de Teologia, t. I. Madri. Taurus. 1967. P. 93-166.

RUETHER, R. "Refletindo sobre criação e destruição - Reavaliação do corpo no ecofeminismo". In: Concilium 295 - 2002/2. Editora Vozes. P. $44[180]-54[190]$.

SOUZA NETO, Medoro Oliveira. Maturidade eclesial,comunhão e ministérios. Umestudo crítico-teológico sobre a participação dos fiéis nas decisões da Igreja, a partir das CEBs. Tese Doutoral, pela Pontifícia Universidade Católica do Rio de Janeiro. 1994.

TILLARD, J. Carne de la Iglesia, carne de Cristo. En las fuentes de la eclesiologia de comunion. Colection Verdad e Imagen. Salamanca/Espanha. Ediciones SIGUEME.

WENDLAND, H.-D.; WARNACH, V. Das Wirken des Hl. Geist in den Gläubigen nach Paulus. In: Pro veritate. Ein theologischer Dialog (Festgabe L. Jaeger u. W. Stählin, dir. por E. Schlinck e H. Voek). Münster e Kassel. 1963.

\section{Dicionário:}

BORN, A. V. Dicionário Enciclopédico da Bíblia. Petrópolis. Ed. Vozes. 1985. 